\title{
Morphotectonics of the central Muertos thrust belt and Muertos Trough (northeastern Caribbean)
}

\author{
J.L. Granja Bruña ${ }^{\text {a,* }}$, U.S. ten Brink ${ }^{\text {b }}$, A. Carbó-Gorosabel ${ }^{\mathrm{a}}$, A. Muñoz-Martín ${ }^{\mathrm{a}}$, M. Gómez Ballesteros ${ }^{\mathrm{c}}$ \\ - Applied Tectonophysics Group, Geodynamics Department, Universidad Complutense de Madrid, josé Antonio Novais, $s / n, 28040$, Madrid, Spain \\ b US. Geological Survey, 384 Woods Hole Roud, Woods Hole, MA 02543, 508-457-2396, USA \\ ' instituto Español de Oceanografía. C/Corazón de María 8, 28002, Madrid Spain
}

\section{A R T I C L E I N F O}

\section{Article history:}

Received 25 February 2008

Received in revised form 7 March 2009

Accepted 18 March 2009

Communicated by D.J.W. Piper

Keywords:

morphotectonics

thrust belt

Muertos Trough

Caribbean plate

\begin{abstract}
A B S T R A C T
Multibeam bathymetry data acquired during the 2005 Spanish $R / V$ Hesperides cruise and reprocessed multichannel seismic profiles provide the basis for the analysis of the morphology and deformation in the central Muertos Trough and Muertos thrust belt. The Muertos Trough is an elongated basin developed where the Venezuelan Basin crust is thrusted under the Muertos fold-and-thrust belt. Structural variations along the Muertos Trough are suggested to be a consequence of the overburden of the asymmetrical thrust belt and by the variable nature of the Venezuelan Basin crust along the margin. The insular slope can be divided into three east-west trending slope provinces with high lateral variability which correspond to different accretion stages: 1) The lower slope is composed of an active sequence of imbricate thrust slices and closed fold axes, which form short and narrow accretionary ridges and elongated slope basins; 2) The middle slope shows a less active imbricate structure resulting in lower superficial deformation and bigger slope basins; 3) The upper slope comprises the talus region and extended terraces burying an island arc basement and an inactive imbricate structure. The talus region is characterized by a dense drainage network that transports turbidite flows from the islands and their surrounding carbonate platform areas to the slope basins and sometimes to the trough. In the survey area the accommodation of the ongoing east-west differential motion between the Hispaniola and the Puerto Rico-Virgin Islands blocks takes place by means of diffuse deformation. The asymmetrical development of the thrust belt is not related to the geological conditions in the foreland, but rather may be caused by variations in the geometry and movement of the backstop. The map-view curves of the thrust belt and the symmetry of the recesses suggest a main north-south convergence along the Muertos margin. The western end of the Investigator Fault Zone comprises a broad band of active normal faults which result in high instability of the upper insular slope.

(c) 2009 Elsevier B.V. All rights reserved.
\end{abstract}

\section{Introduction}

The offshore areas of the Northeastern Caribbean Boundary Zone have been widely studied since the 1950 s, but most studies have focused on the north slope of the islands of Hispaniola and Puerto Rico (e.g., Larue and Ryan, 1998; Dolan et al., 1998; ten Brink et al., 2004). Very few studies have been carried out on the south slope. A few cruises with seismic data acquisition provide some information about the seismic stratigraphy of the Venezuelan Basin, the Muertos Trough and the Muertos deformed belt (IG1503 cruise (Ladd et al., 1977), IG2408 cruise (Ladd et al., 1981), EW9501 cruise (Driscoll and Diebold, 1999) and SEACARIB I cruise (Mauffret and Leroy, 1999)). During spring 2005 a marine geophysical cruise aboard the Spanish Oceanographic Research Vessel Hespérides was carried out in this area of the northeastern Caribbean plate (GEOPRICO-DO), and

\footnotetext{
* Corresponding author. Tel: +34 648155 691; fax: +34913944631.

E-maï addresses: jlgranja@geo.ucm.es (J.L Granja Bruña), utenbrink@usgs.gov (U.S. ten Brink), maria.gomez@md.ieo.es (M. Gómez Ballesteros).
}

specifically in a broad region of the southern insular slope (Figs. 1, 3a; Carbó et al., 2005).

The east-west trending Muertos Trough takes its name from the largest island off the south coast of Puerto Rico, Caja de Muertos (Glover, 1971; Mann et al., 2005) (Fig. 1). In the north-eastern Caribbean bibliography both trench and trough are used indistinctly for the Muertos depression. Some authors have used trough on the basis of the shallower structure (Matthews and Holcombe, 1974; Case and Holcombe, 1980; Forsthoff and Holcombe, 1983) and others used trench (Ladd and Watkins, 1978) to signify an underthrusting process of the Caribbean's interior beneath the island arc. Byrne et al. (1985) considered a subduction process taking place along the Muertos "Trough". Later bibliography used trough and trench always from the standpoint of a subduction process (Dillon et al., 1996; Dolan et al., 1998; Mann et al., 2002; Mann et al., 2005). However, the depth distribution of earthquakes does not show a clear subduction process (i.e., Wadati-Benioff Zone) taking place along the Muertos margin (Dillon et al., 1996; Dolan et al., 1998; Mann et al., 2002). Nowadays, in the bibliography and in the geology glossaries, the term "trench" is 


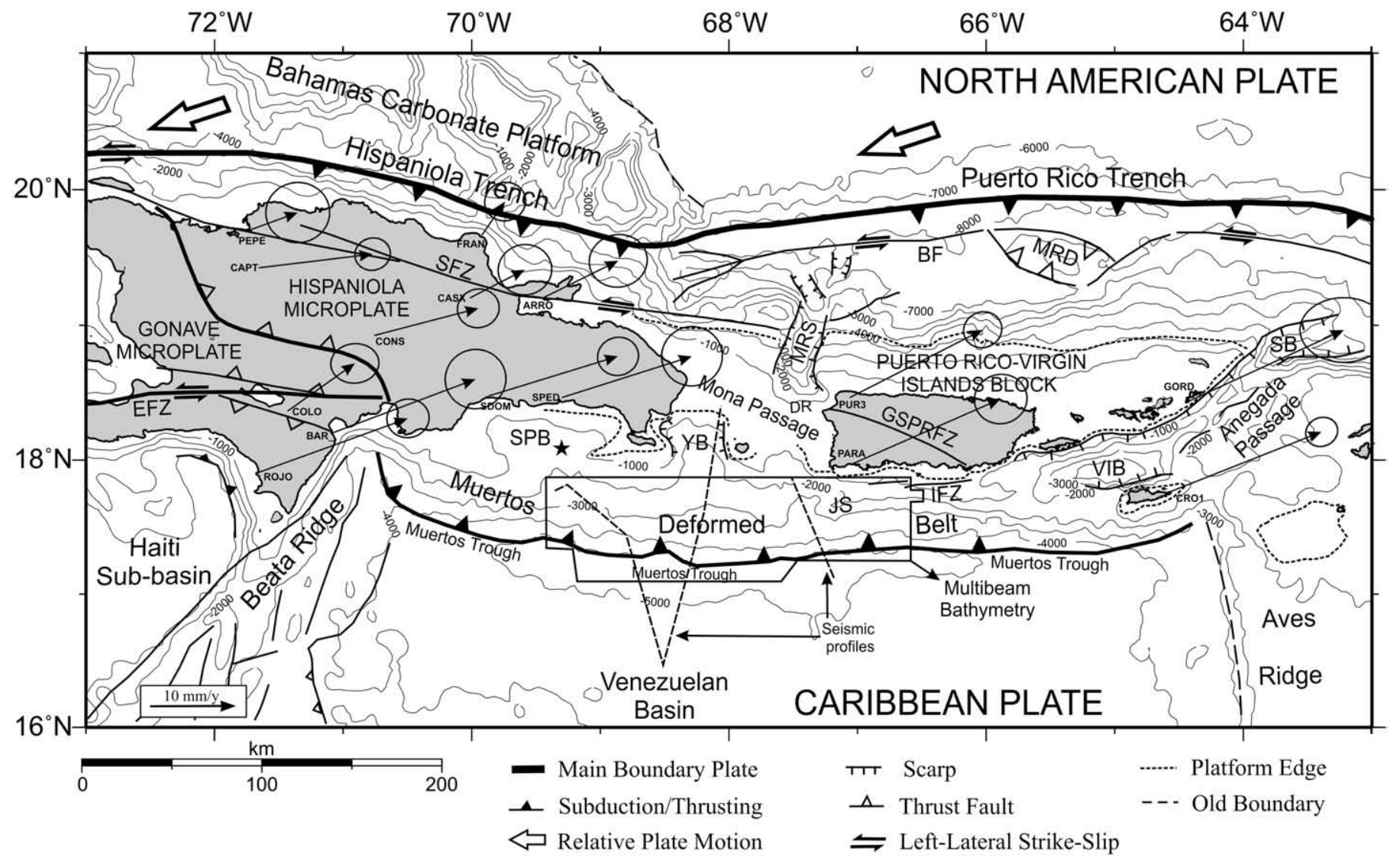

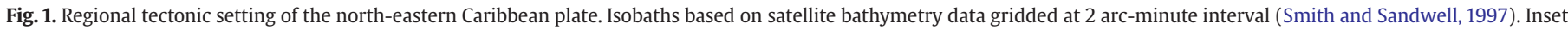

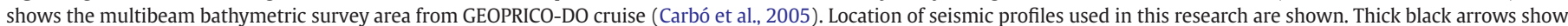

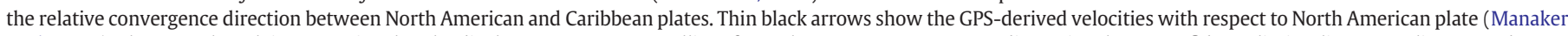

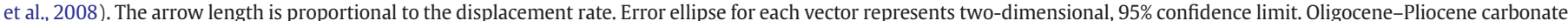

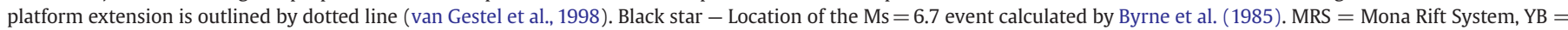

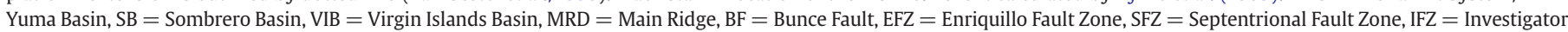
Fault Zone, JS = Jaguey Spur, SPB = San Pedro Basin, DR = Desecheo Ridge, GSPRFZ = Great Southern Puerto Rico Fault Zone.

used in most cases associated to a subduction process (Kearey, 2001; Allaby, 2008). Therefore, we avoid using "trench" and "accretionary prism" since these terms are generally linked with subduction zones. Instead, we use trough and thrust belt.

The Muertos tectonic area can be classified as a convergent margin where a variably thick pile of pelagic and turbiditic sediments has been accreted to produce a deformed belt (Matthews and Holcombe, 1974; Ladd et al., 1977; Case and Holcombe, 1980). Seismic reflection data from other convergent margins around the world show that part or all of these sediments and rocks are offscraped and accreted forming a sequence of imbricate thrust slices (e.g., Barbados (Moore and Biju-Duval, 1984); Cascadia (Davis and Hyndman, 1989); Makran (Kopp et al., 2000); Costa Rica (Shipley et al., 1992)). The morphological expression of the imbricate slices is a sequence of elongated, narrow, sub-parallel ridges. The thrust slices characteristically show a seaward slope steeper than the landward slope (Kukowski et al., 2001). The accreted pelagic sediments come from the foreland region, whereas the turbiditic sediments are mainly of island arc origin. Deep erosive canyons may form by the turbidity currents, where the rivers carry abundant suspended material from onshore areas to the margin (Gnibidenko and Svarichesvskaya, 1983; Underwood, 1991; Hagen et al., 1994). A similar convergent setting is found in the Muertos margin (Ladd et al., 1977; Byrne et al., 1985). Muertos margin features are influenced by an overriding block which is partitioned into microplates (Jansma et al., 2000; Mann et al., 2002), and by convergence and thrusting of a "buoyant" oceanic plateau (i.e., Venezuelan Basin crust; Burke et al., 1978). This thrust belt and its associated trough are the result of a convergence process in a retroarc area of the eastern Greater Antilles island arc (ten Brink et al., in press). The convergence is mainly resolved by perpendicular thrusting of the eastern Greater Antilles island arc over the Venezuelan Basin crust (Fig. 1).

The purpose of this paper is to analyze the morphotectonics and the shallower structure of the central part of the Muertos thrust belt and the Muertos Trough, and to document the spatial variations along and across these features. We present a tectonic interpretation from the integration of new multibeam bathymetry data acquired during the GEOPRICO-DO cruise and reprocessed seismic reflection profiles. The role of the canyons and channels in the superficial mass transfer and the supply to the Muertos Trough is investigated. We also address several other outstanding issues resulting from the detailed observation and analysis of the data such as the convergence vector and the microplates setting of the northeastern Caribbean.

\section{The tectonic setting of the Muertos convergent margin}

\subsection{The Muertos margin in the Caribbean plate setting}

During most of the Tertiary, the Caribbean plate has been moving eastward with respect to the North and South American plates, assisted by left-lateral strike-slip systems in the northern boundary and right-lateral strike-slip systems in the southern boundary (Weber et al., 2001; Mann et al., 2002). These boundaries act as broad bands of deformation in which transtension and transpression take place, as well as microplates and blocks tectonics (Byrne et al., 1985; Reid et al., 1991; Mann et al., 1995; Jansma et al., 2000). Oblique 
convergence along these boundaries adds more tectonic complexity and as a result, compressional structures such as deformed belts and troughs have been developed along the northern (Muertos margin, Fig. 1) and southern margins of the Venezuelan Basin (Ladd and Watkins, 1979).

\subsection{Regional setting of the Muertos margin}

The eastern Greater Antilles island arc consists of a series of microplates: Gonave microplate (Mann et al., 1995), Hispaniola microplate (Byrne et al., 1985) and Puerto Rico-Virgin Islands block
(Jansma et al., 2000) (Fig. 1). These microplates are located within the $250 \mathrm{~km}$-wide northeastern Caribbean plate boundary zone (Ladd and Watkins, 1978; Mann and Burke, 1984, Mann et al., 1995; Byrne et al., 1985: Ladd et al., 1990; Masson and Scanlon, 1991; Dillon et al., 1996). GPS-derived velocities indicate that the Caribbean plate is moving relative to the North American plate at a rate of $18-20 \mathrm{~mm} / \mathrm{yr}$ in an azimuth of $070^{\circ}$ (Mann et al., 2002) (Fig. 1). The main boundary between the North American and the Caribbean plates is situated along the Puerto Rico Trench (Fig. 1). In this trench, highly oblique convergence is accommodated by a predominantly east-west leftlateral strike-slip motion (e.g., Bunce Fault, BF in Fig. 1; ten Brink and
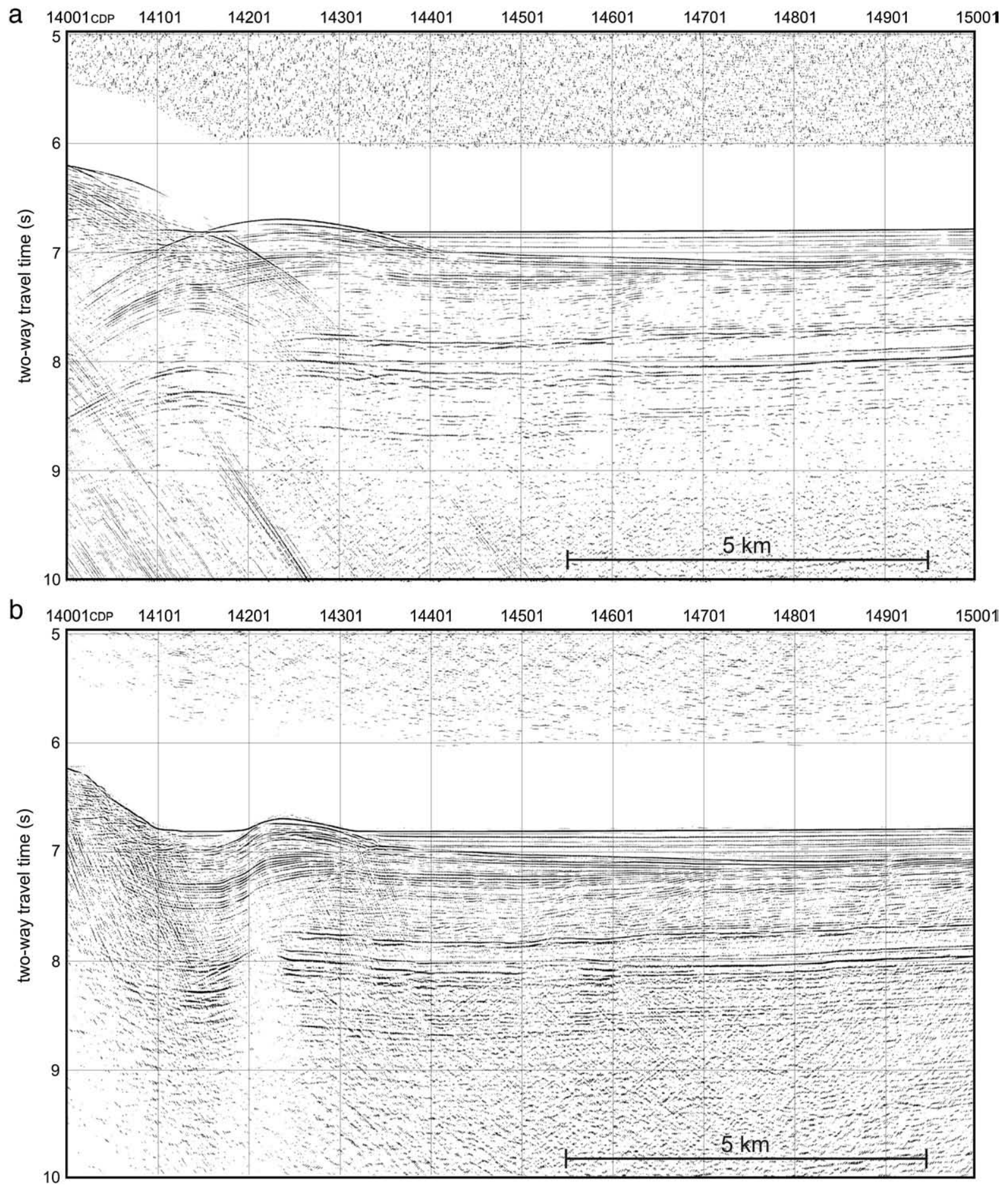

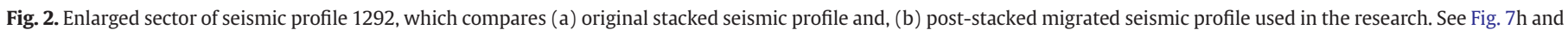
Fig. 9a for location. Vertical scale is given in seconds (twtt). Vertical exaggeration is $\sim 2.0$ at the seafloor. 


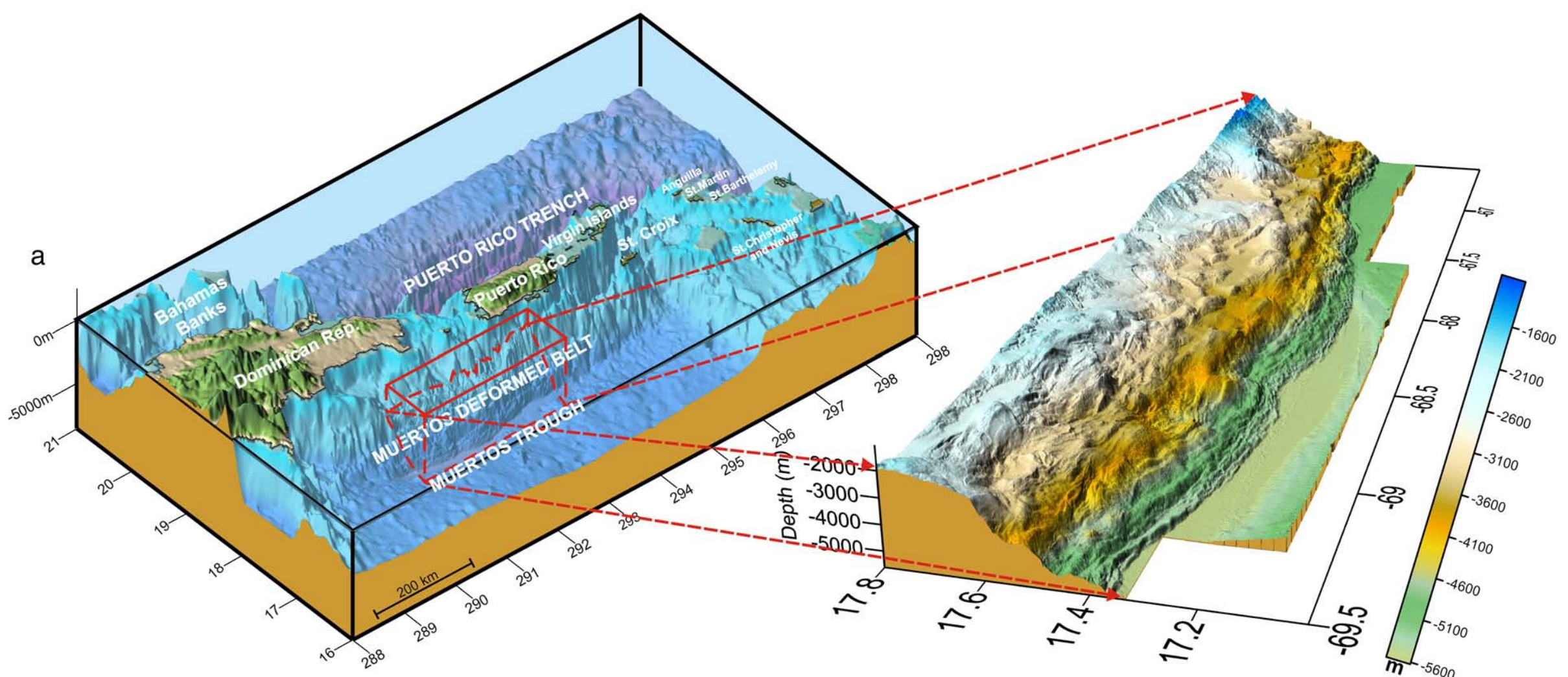

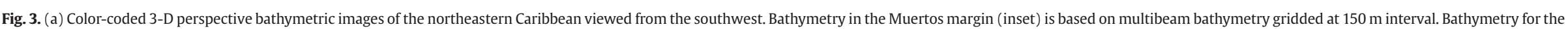

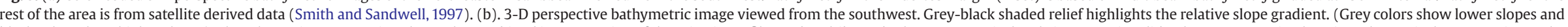

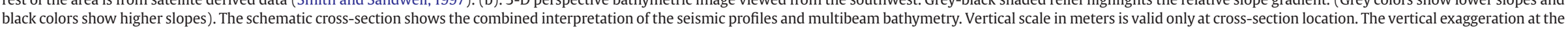
cross-sections is $\sim 7$. See Fig. 5b for location. (c) Same as (b), but view from the southeast. See Fig. 5b for location. 

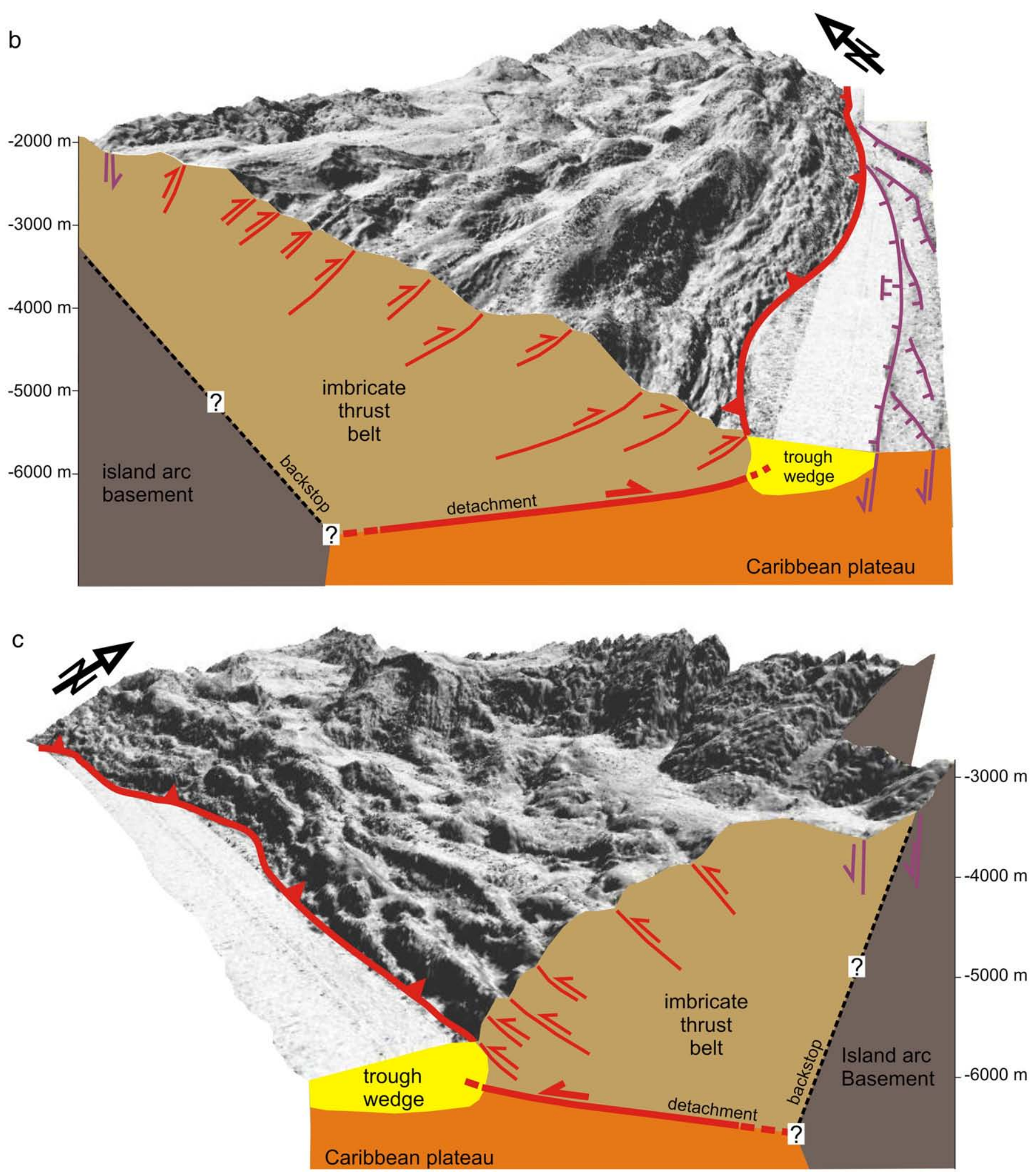

Fig. 3 (continued).

Lin, 2004, 2005) with only a small component of subduction of the North American plate beneath the Caribbean plate (Calais et al., 2002; Mann et al., 2002; Manaker et al., 2008). In this setting, the Muertos convergent margin is an east-west trending tectonic feature located in the retroarc region of an inactive Cretaceous to Early Tertiary island arc and is a result of the convergence between the North American and the Caribbean plates (Ladd et al., 1981; Dillon et al., 1996).
Interpretations of the gravity (Worzel and Ewing, 1954), seismic reflection (Matthews and Holcombe, 1974; Ladd et al., 1977; BijuDuval et al., 1982) and seismologic data (Byrne et al., 1985, Mann et al., 1991; Dillon et al., 1996; Dolan et al., 1998; Mann et al., 2002) have suggested that the Caribbean plate was possibly being underthrusted or subducted under Puerto Rico and Hispaniola. Seismic data show that reflectors corresponding to the Venezuelan 
a
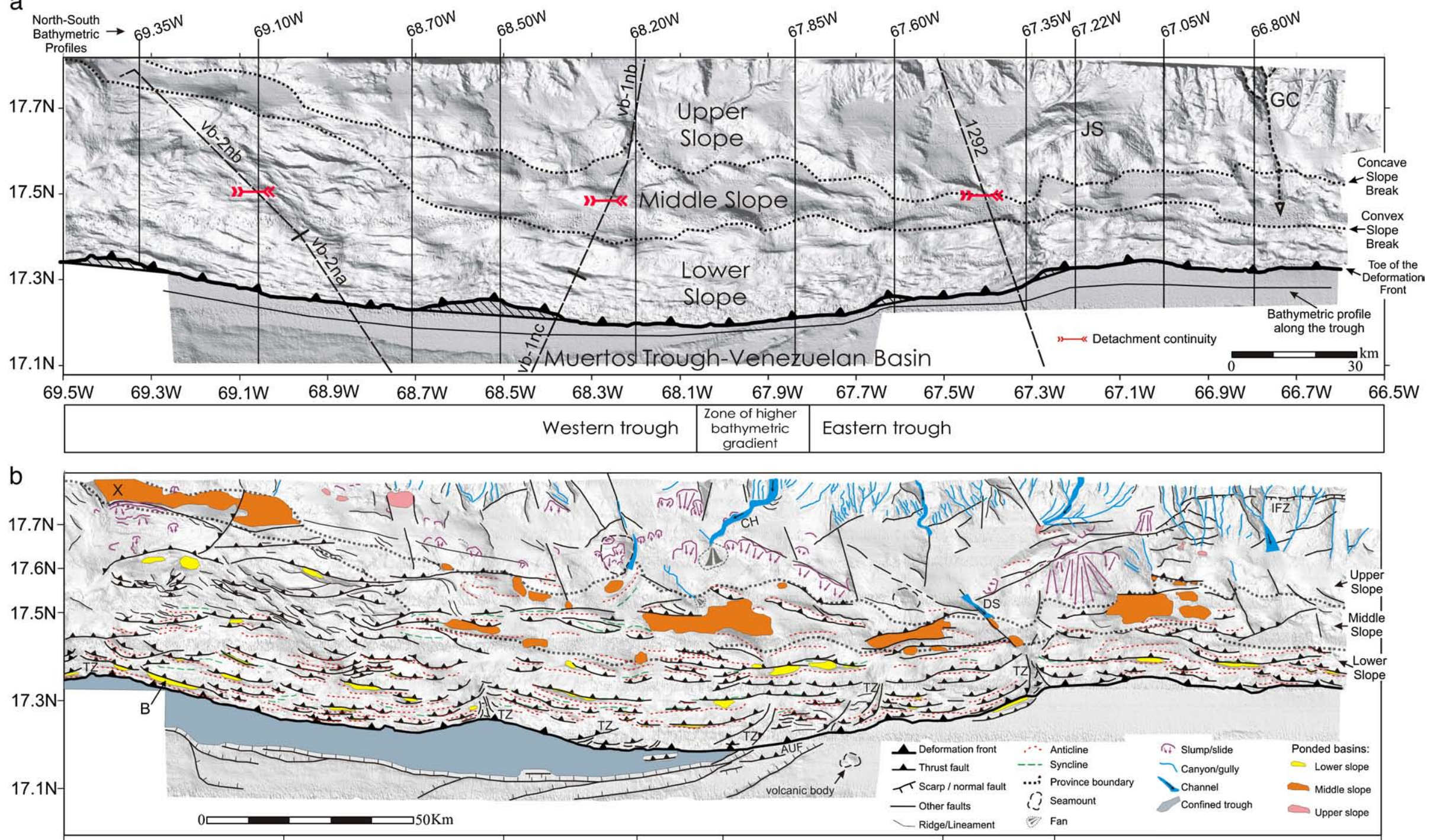

$69.5 \mathrm{~W}$

$68.5 \mathrm{~W}$

$68.2 \mathrm{~W}$

$67.5 \mathrm{~W}$

67.25W

$66.5 \mathrm{~W}$

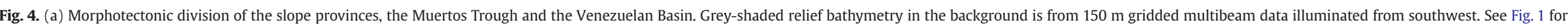

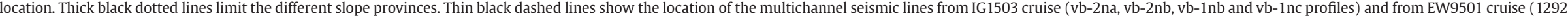

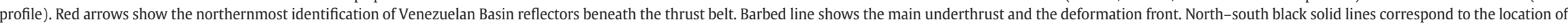

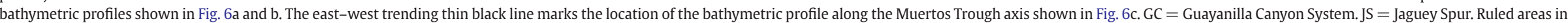

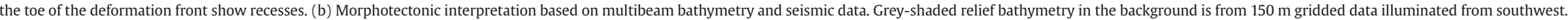

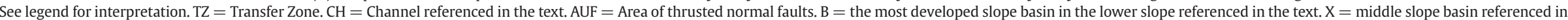

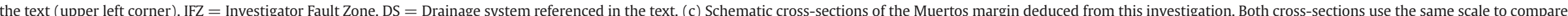
the variation along the margin. Top figure shows the cross-section of the western region (south of Mona Passage). Bottom figure shows the eastern region (south of Puerto Rico). 

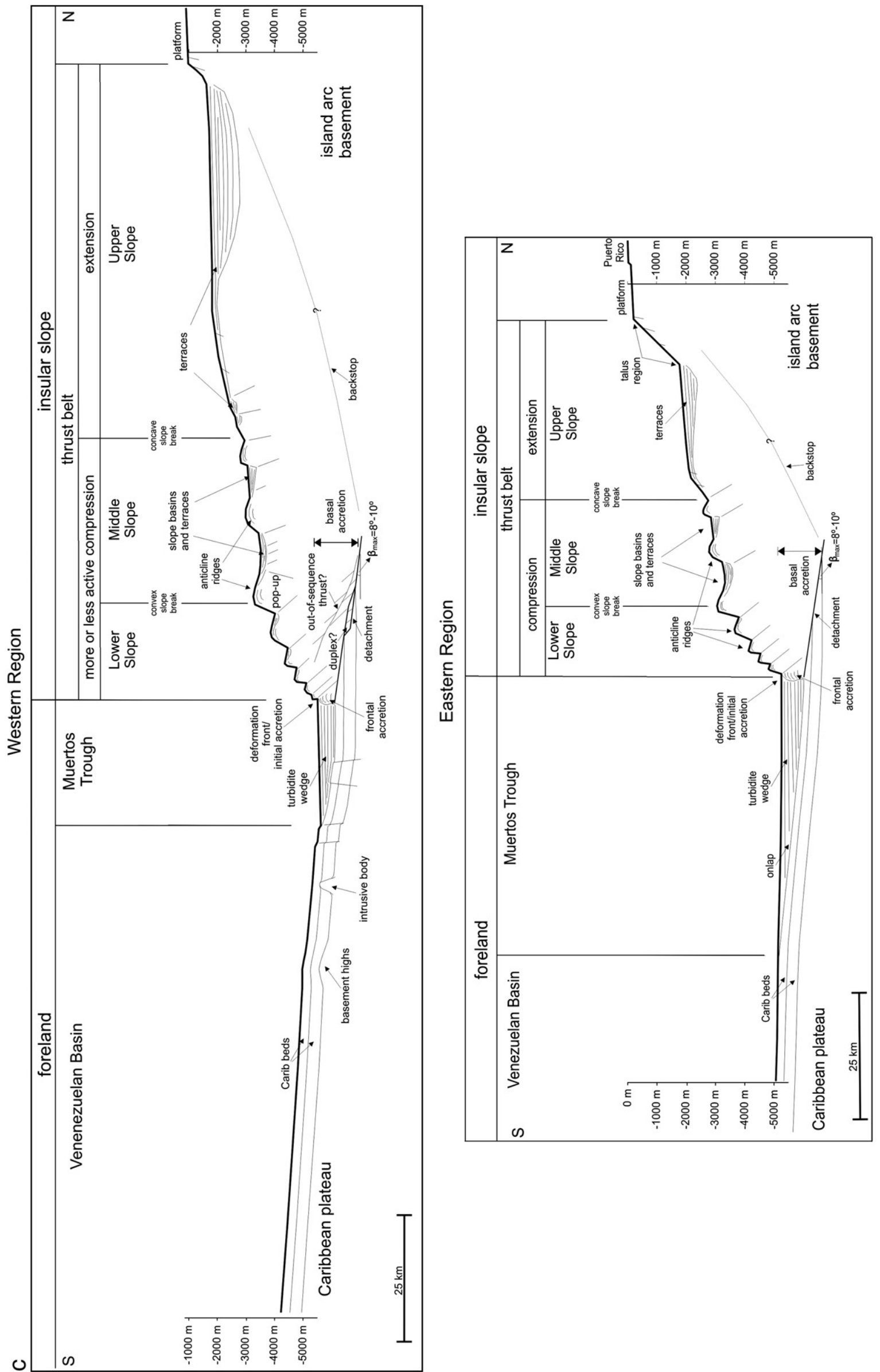

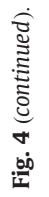


a

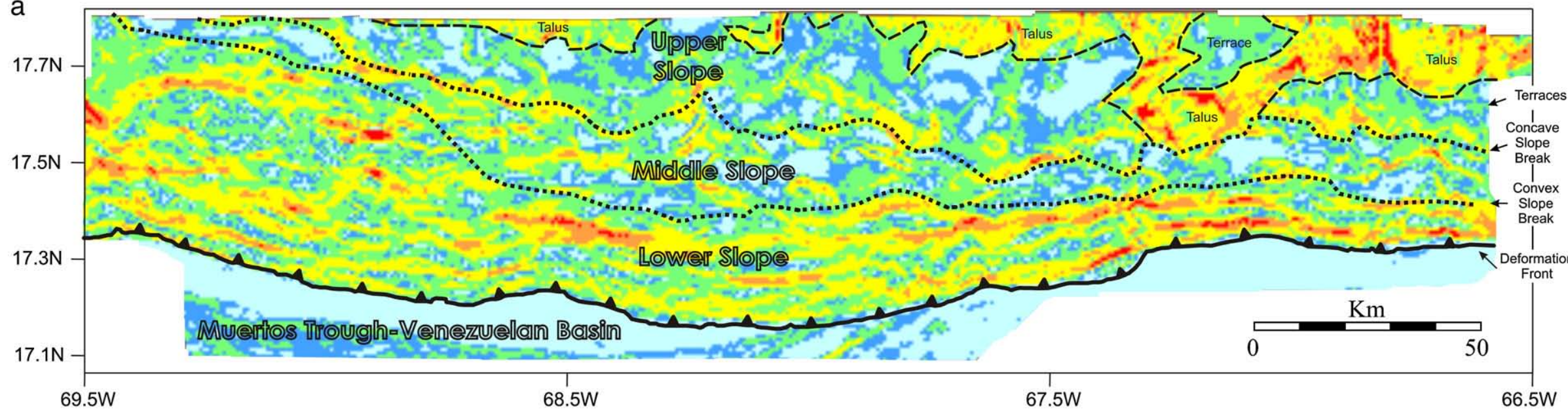
$69.5 \mathrm{~W}$

$68.5 \mathrm{~W}$

$67.5 \mathrm{~W}$

$66.5 \mathrm{~W}$
Slope Legend
$0^{\circ}-1^{\circ}$
$1^{\circ}-2^{\circ}$
$2^{\circ}-5^{\circ}$
$5^{\circ}-10^{\circ}$
$10^{\circ}-14^{\circ}$
$15^{\circ}<$

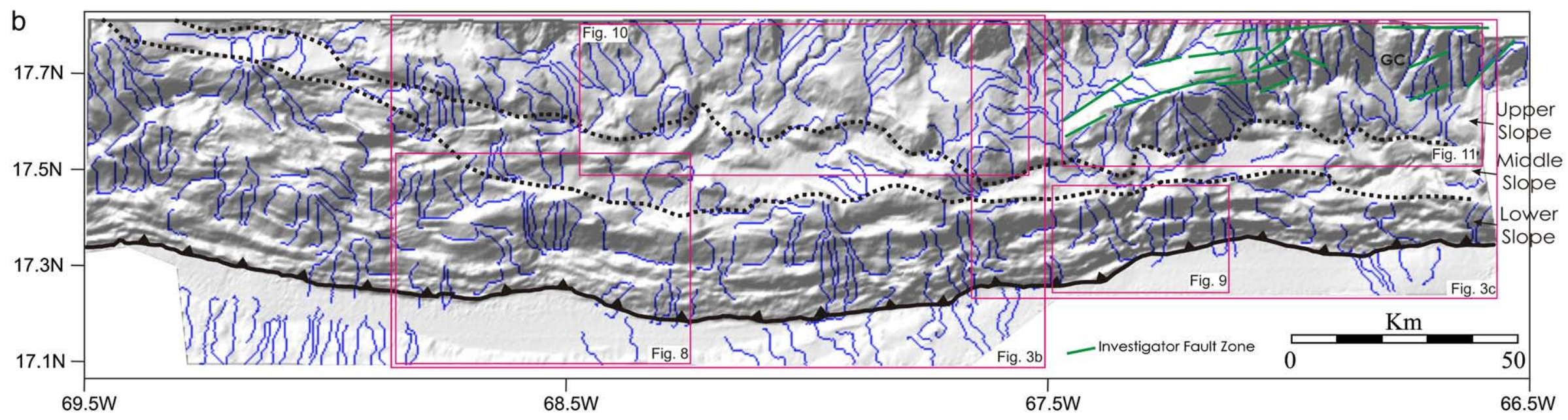

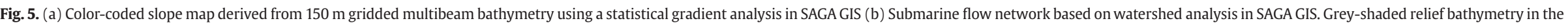
background comes from $150 \mathrm{~m}$ gridded multibeam data illuminated from southwest. Insets show the location of different figures of the manuscript. Traces of the Investigator Fault Zone are marked by green lines. 


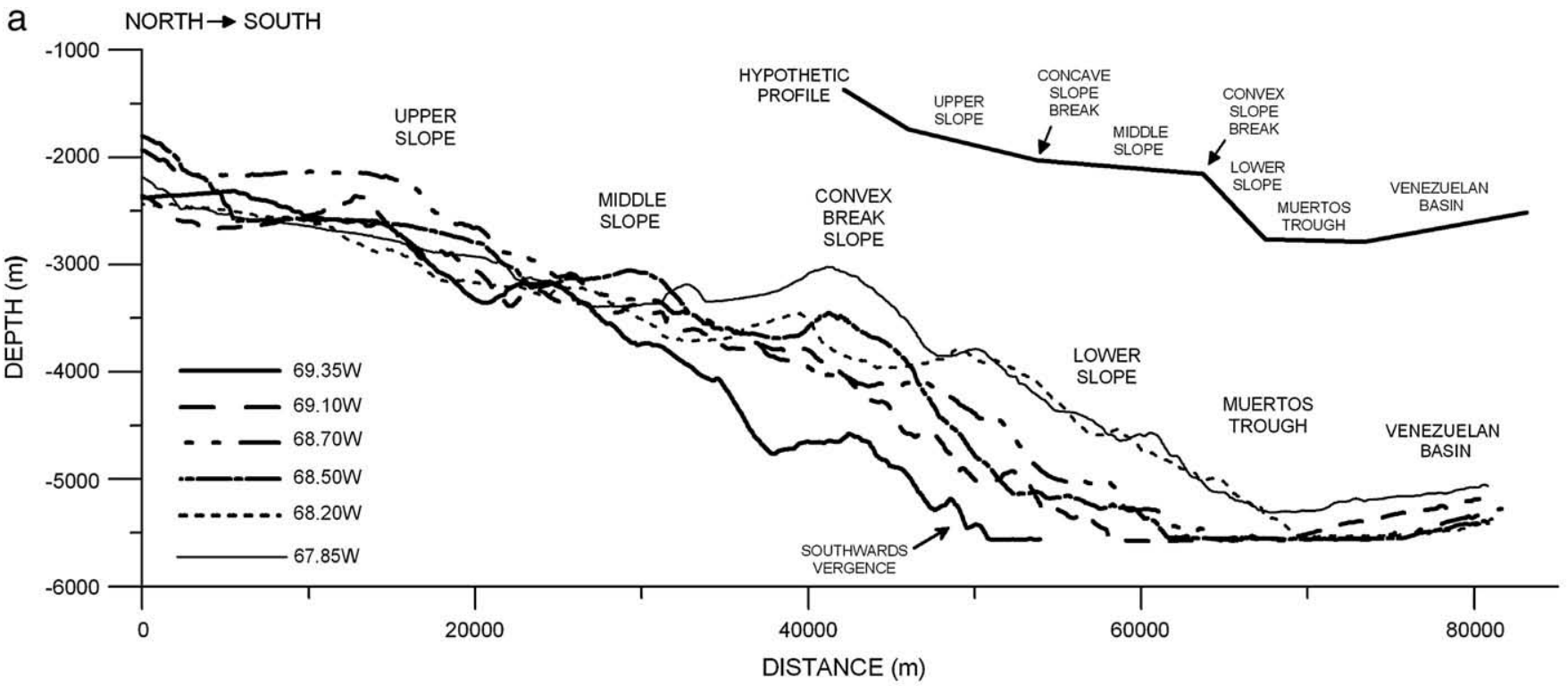

b
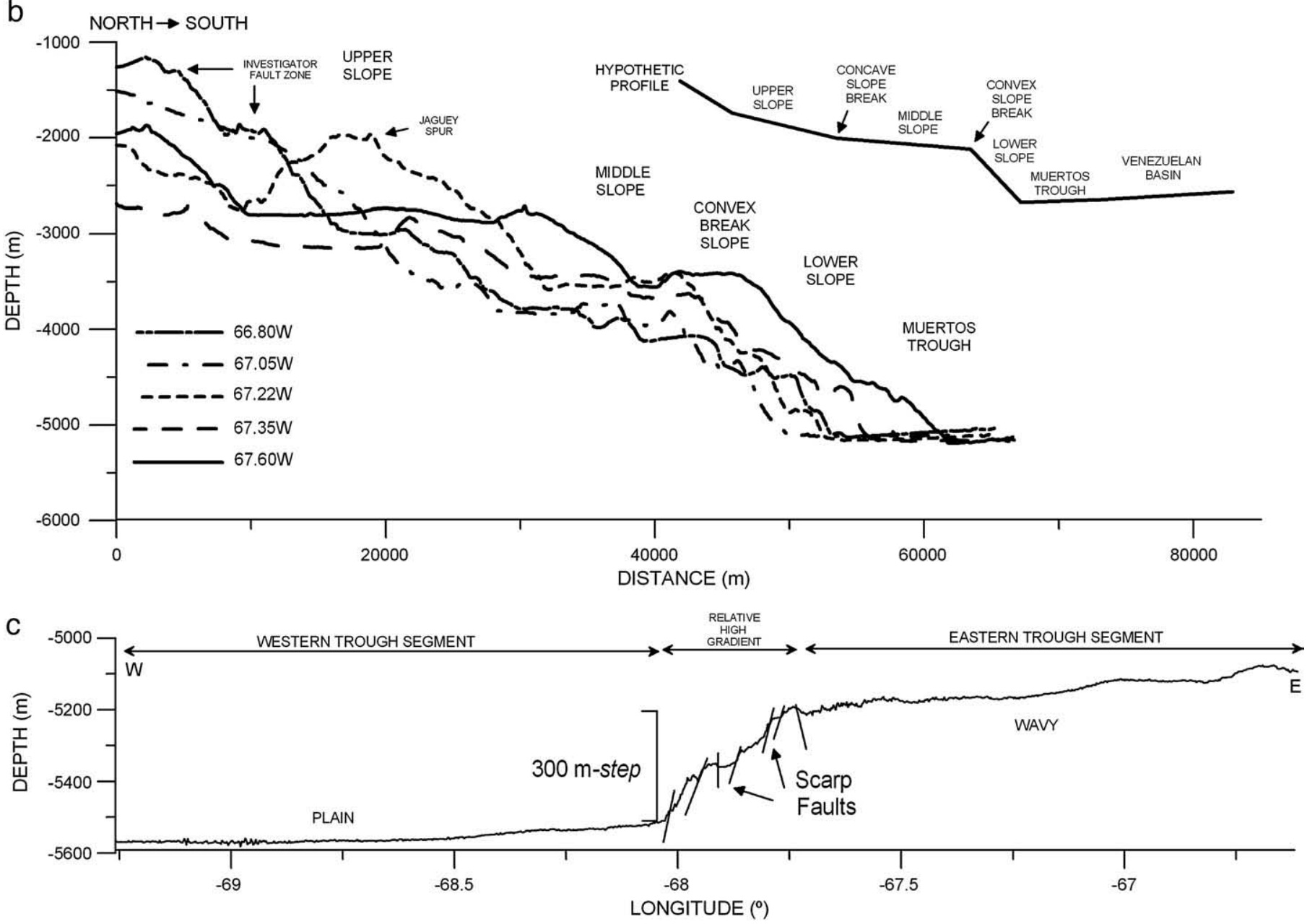

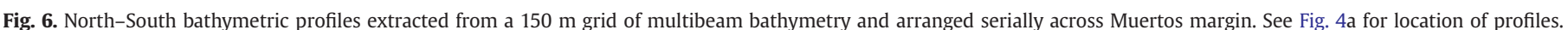
(a) Western trough. (b) Eastern trough. (c) Bathymetric profile along the Muertos Trough.

Basin extend beneath the south insular slope (Matthews and Holcombe, 1974; Ladd et al., 1977, 1981). Moreover, the San Pedro Basin, a thicker "forearc basin", lies north of the "accretionary wedge" (i.e., "Muertos Accretionary Prism"), south-east of Hispaniola (SPB in Fig. 1). Overall, the trench-wedge-forearc basin sequence closely resembles island arc sequences observed around the Caribbean and the Pacific (Ladd and Watkins, 1978, 1979).

Although oblique convergence between the North American and the Caribbean plates has been taking place since the Jurassic (Mann, 1999), the time when the Muertos margin originated is still unclear. 
Some workers have argued that Muertos Trough subduction ceased around the late Eocene (Burke et al., 1978) or Oligocene (Malfait and Dinkelman, 1972). On the other hand, Byrne et al. (1985), Dillon et al. (1996) and Dolan et al. (1998) suggest active subduction processes from seismological data. Byrne et al. (1985) interpreted the June 24, 1984, Ms =6.7 San Pedro Basin event (black star in Fig. 1), to be a nearly pure thrust motion along a plane dipping $9^{\circ}$ northwards at $32 \mathrm{~km}$ focal depth. Dillon et al. (1996) and Dolan et al. (1998) estimated the three-dimensional geometry of a $15^{\circ}$ northwarddipping zone of seismicity associated with the northward underthrusting of Caribbean lithosphere along the Muertos Trough. This strongly suggests that the Muertos Trough is an active convergent boundary.

Morphologically, the Muertos Trough is an east-west trending depression which is slightly concave to the north. This trough is $650 \mathrm{~km}$ long and runs from the Beata Ridge in the west to the insular slope of the Aves Ridge in the east (Matthews and Holcombe, 1974; Case and Holcombe, 1980) (Fig. 1). The trough is a striking bathymetric feature with water depths greater than $-5550 \mathrm{~m}$ (Granja et al., 2006). The reflecting horizons of the Venezuelan Basin, the "Carib beds" (Coniacian-recent materials mainly pelagic and volcanic, Ewing et al., 1968; Edgar et al., 1971, 1973) gently dip to the north beneath the turbidite fill of the trough and continue beneath the insular slope (Ladd et al., 1977). The insular slope along the Muertos Trough is formed by an east-west deformed belt or accretionary prism (Matthews and Holcombe, 1974; Ladd et al., 1990; Case and Holcombe, 1980; Jany, 1989). The maximum convergence estimated along this margin south of Hispaniola is $3 \mathrm{~mm} / \mathrm{yr}$ (Calais et al., 2002) or $7.7 \mathrm{~mm} / \mathrm{yr}$ (Mann et al., 2002), but convergence decreases eastwards until about $65^{\circ} \mathrm{W}$, where the deformed belt disappears (Jany, 1989; Masson and Scanlon, 1991). The convergence between the island arc and the Venezuelan Basin crust was proposed to be transferred or linked by means of strikeslip faults (e.g., Investigator Fault Zone, IFZ in Fig. 1) to the Anegada Passage (Jany, 1989; Masson and Scanlon, 1991; van Gestel et al., 1998; Mann et al, 2005).

The western end of the Muertos Trough is deflected to the north and becomes shallower. Some researchers have suggested that the Muertos margin structure continues westwards into Hispaniola but the geometry of the transition is still unclear (Biju-Duval et al., 1982; Mann et al., 1995) (Fig. 1).

\section{Data}

We present new multibeam bathymetry data acquired south of the Dominican Republic and Puerto Rico (Figs. 1, 4a) as part of the 2005 GEOPRICO-DO cruise (Carbó et al., 2005). The region was systematically mapped using the Simrad EM-120 multibeam system installed on the Spanish $R / V$ Hespérides with $100 \%$ coverage of the seafloor (Fig. 3a). This echo-sounder is designed to work between $1000 \mathrm{~m}$ and $11000 \mathrm{~m}$ water depth with a measured precision between $0.5 \%$ and $1 \%$ of the water depth. The survey covered an area of approximately of $23000 \mathrm{~km}^{2}$, between water depths of $-1000 \mathrm{~m}$ and $-5550 \mathrm{~m}$ (see survey area in Fig. 1 and Fig. 3a) with only a small gap ( $2500 \mathrm{~m}$ by $700 \mathrm{~m}$ ), which was interpolated. A total of $3865410\left(\sim 170\right.$ soundings $\left./ \mathrm{km}^{2}\right)$ soundings were collected. The data was examined for quality, edited, and processed using the software Neptune (Simrad) and IRAP-CFloor (Smedvig AS). Maps were created using the commercial Golden Software Surfer v8.0, and the free software GMT (Wessel and Smith, 1998) and SAGA GIS (Göttingen University).

To augment the interpretation of the bathymetry we have reprocessed five stacked seismic reflection records provided by the University of Texas at Austin (Marine Seismic Data Center, Shipley et al., 2005). Stacked profiles vb-1nb, vb-2na and vb-2nb from IG1503 cruise have been partially published in Ladd et al.
(1977) and Ladd and Watkins (1978). However, the profiles vb-1nc and 1292 from IG1503 (1975) and EW9501 (1995) cruises respectively have not been previously published (Seismic profiles location in Figs. 1, 4a). A detailed re-processing by means of post-stack Memory Stolt $\mathrm{f}-\mathrm{k}$ migration method has improved the seismic images (Fig. 2; Stolt, 1978). The reprocessed seismic profiles provide valuable information about the seismic stratigraphy of the Venezuelan Basin and the Muertos Trough, and about the structure of the south insular slope.

\section{Morphology of the Muertos Trough and the Muertos thrust belt: tectonic interpretation}

We have divided the region into four east-west trending provinces on the basis of morphological, structural and sedimentological criteria established from bathymetry and seismic data. The different provinces from south to north are (Figs. 4, 5): the Muertos Trough and Venezuelan Basin, the lower slope, the middle slope and the upper slope. The morphotectonic interpretation of the multibeam bathymetry region is shown in Fig. $4 \mathrm{~b}$ and the schematic morphostructural cross-sections of the margin are shown in Fig. 4c.

\subsection{Muertos Trough and Venezuelan Basin}

The Muertos Trough and the Venezuelan Basin are located in the southern part of the study area (Fig. 4a, c). This province extends from the deformation front southward to the southern end of the multibeam data $\left(\sim 17.1^{\circ} \mathrm{N}\right)$. The axial slope of the Muertos Trough becomes deeper from east to west (Figs. 3a, 6c) with a maximum depth of about $-5580 \mathrm{~m}$. The trough is marked by a smooth seafloor with slopes $\sim 0^{\circ}$ (Figs. 3a, b, c; 5a, 6c). The trough is characterized by a well-defined wedge of series of smooth, closely spaced, sub-parallel reflectors with high seismic reflectivity (Fig. 7 a, c, d). Core samples indicate that the trough seafloor is composed of sediments of different sources, mainly interbedded turbiditic and pelagic sediments underlain by homogeneous carbonate pelagic mudstones and siltstones of the Venezuelan Basin (Forsthoff and Holcombe, 1983). The turbidite wedge, defined by horizontal reflectors, is separated from the Venezuelan Basin layers by a basal unconformity (Figs. 4c, 7a, c, d).

The Venezuelan Basin region has been investigated by seismic surveys (Edgar et al., 1971; Diebold et al., 1981; Diebold et al., 1999) and DSDP data (sites 146/149; Edgar et al., 1971). This region shows a sedimentary cover known as Carib beds. The Carib beds were defined as $1 \mathrm{~s}$ (twtt) of sediments overlaying a Coniacian basalt (top of the Caribbean plateau) marked by the B" reflector (Ewing et al., 1968; Edgar et al., 1971, 1973). Two seismic reflectors are regionally identifiable inside the Carib beds, the $\mathrm{A}^{\prime \prime}$ reflector (Middle Eocene siliceous limestone and chert) and the $\alpha$ reflector (Early Miocene) (Fig. 7a, c, d). In our survey area, these reflectors have high lateral continuity and dip gently northward. They can be traced beneath the turbidite wedge and beneath the south slope for at least $30 \mathrm{~km}$ northwards of the deformation front (Figs. 4c, 7a). A detachment surface separates the sub-horizontal reflectors of the Venezuelan Basin from the overlying steeply-dipping reflectors of the deformed belt (Fig. 7a). The detachment surface propagates southwards by means of blind thrusts deforms the horizontal turbidite layers of the trough wedge (Fig. 7c, d, f). If we consider a $p$ wave velocity, $\mathrm{Vp}=2$ $500 \mathrm{~m} / \mathrm{s}$ for the materials of the thrust belt, the restored dip of the detachment surface has low angles between $8^{\circ}$ and $10^{\circ}$ (Figs. 4c, 7a). The thrust fault offscrapes progressively the trough wedge layers and then the Carib beds (Fig. 7c). Material offscraped from the trough wedge and the Venezuelan Basin cover is added to the thrust belt by frontal and basal accretion (Figs. 2b, c; 4c, 7). In the inner part of the thrust belt, the detachment could be placed near the top of the Caribbean plateau ( $\mathrm{B}^{\prime \prime}$ reflector). This horizon is a good candidate for a detachment surface because of the differences between the 
CDP9001

$10001 \quad 11001$

12001

13001

14001

15001

1600

16801
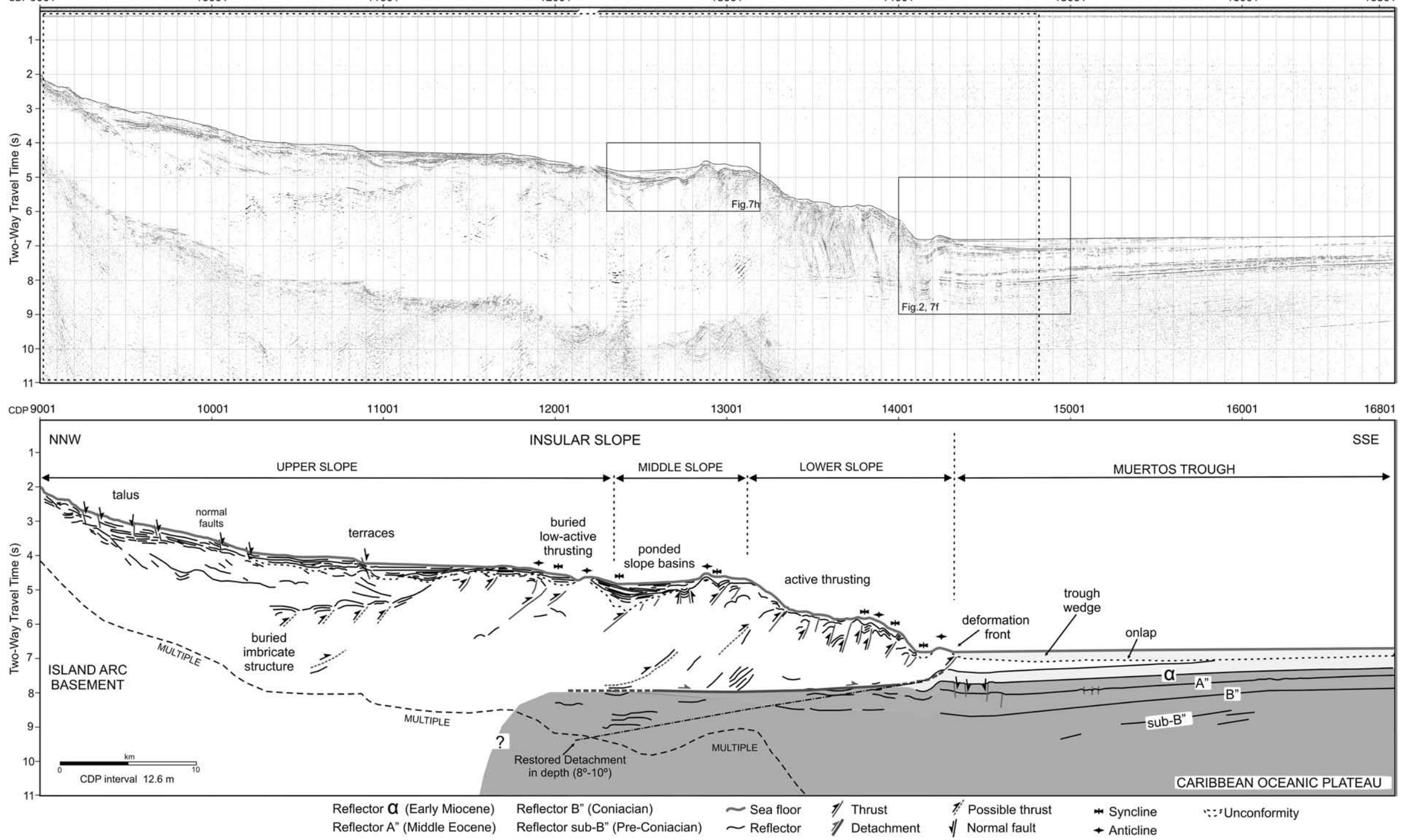

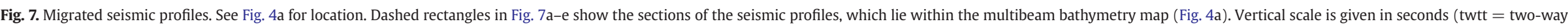

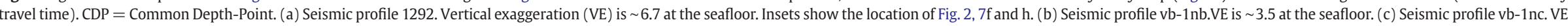

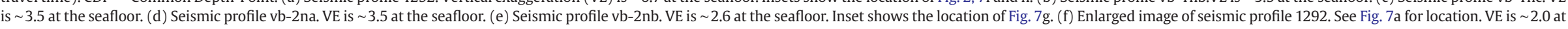

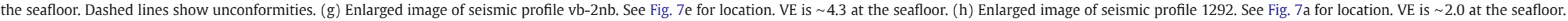
Dashed lines show unconformities. 

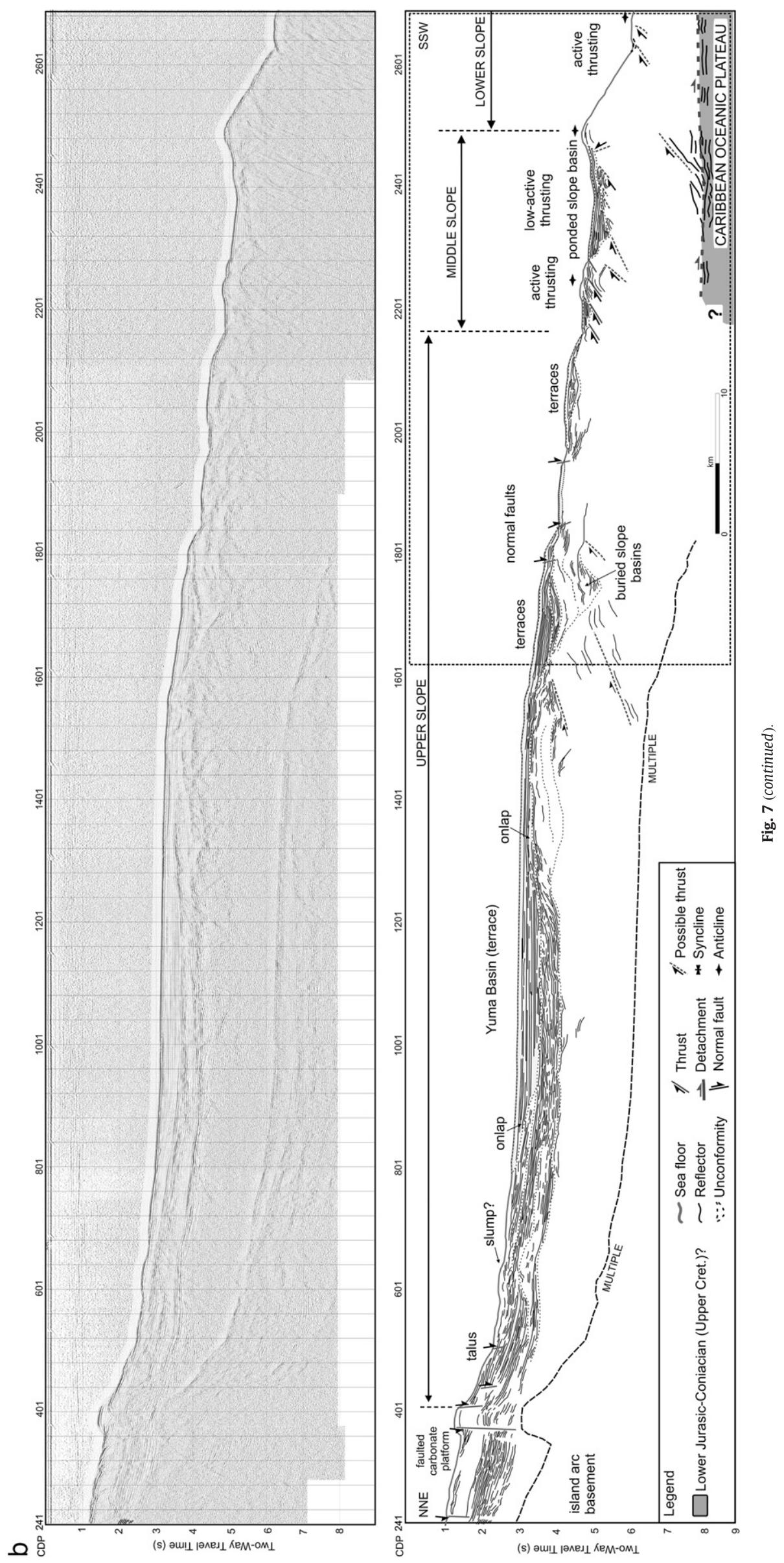

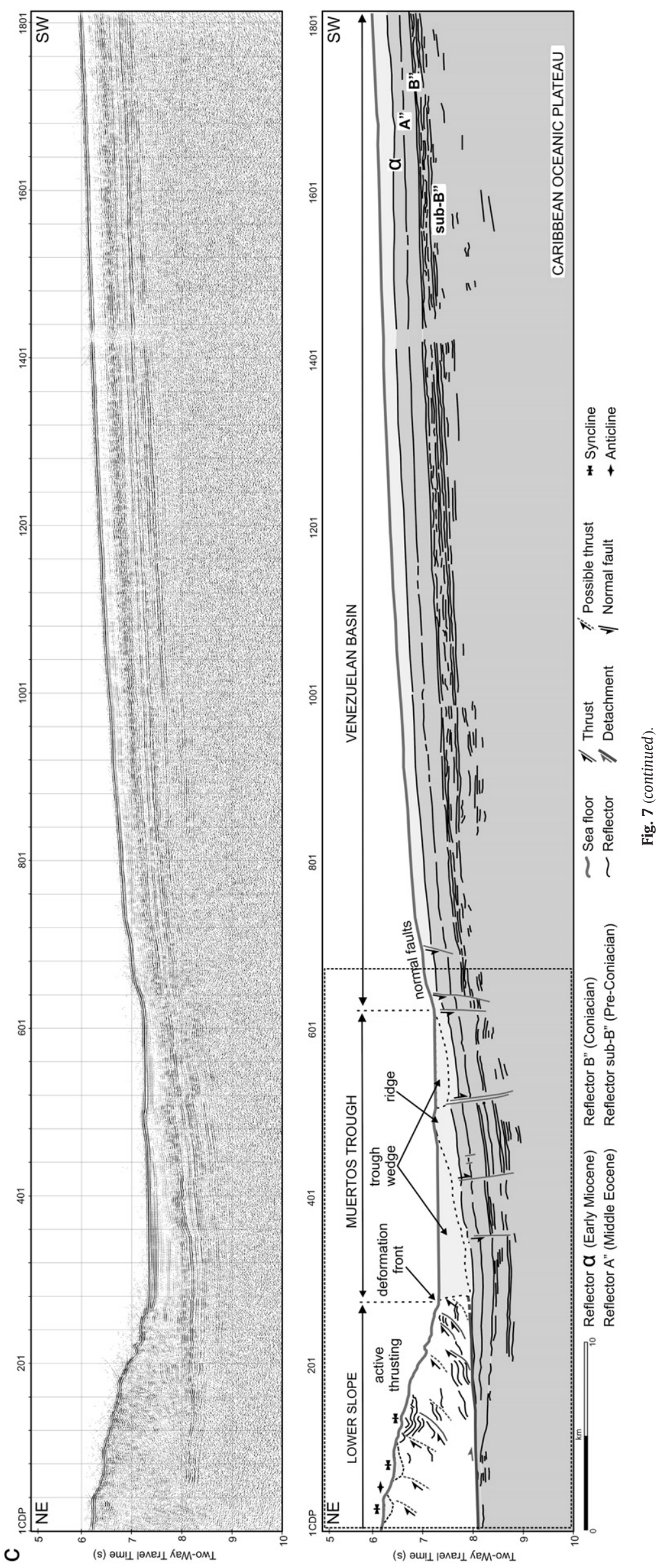

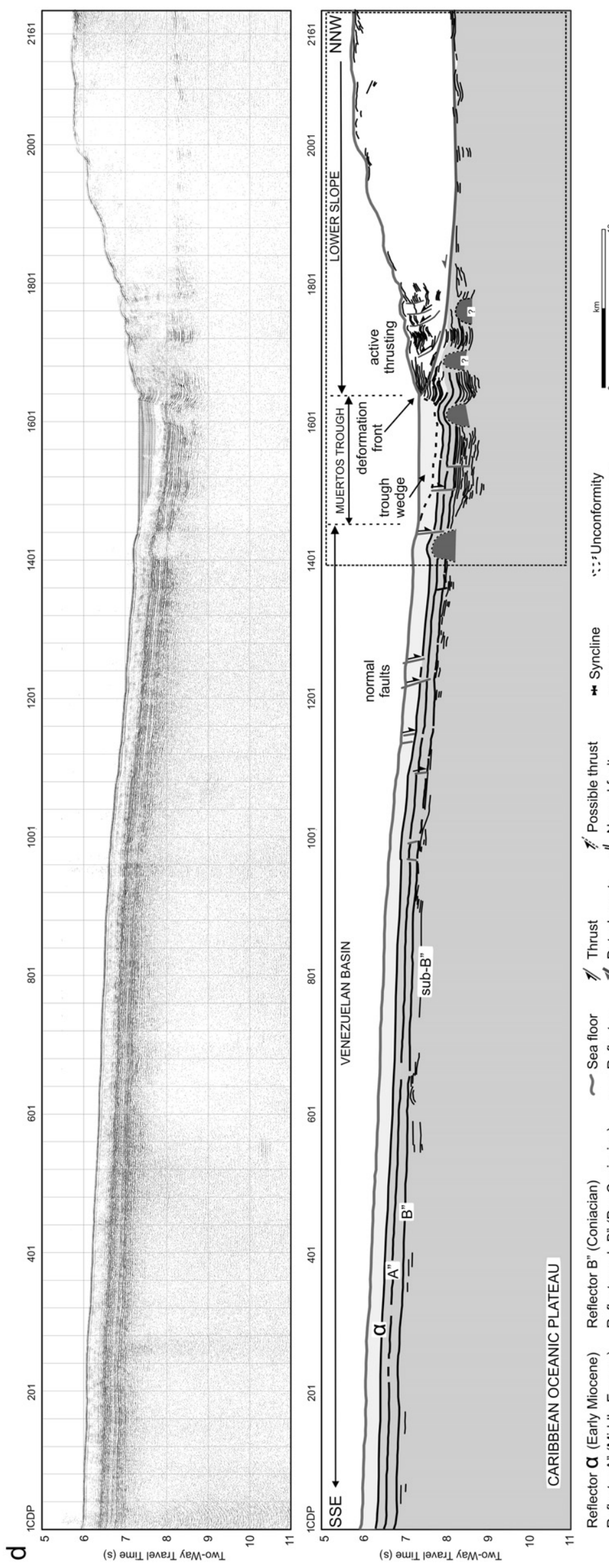

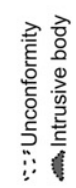

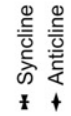

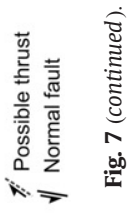

亏

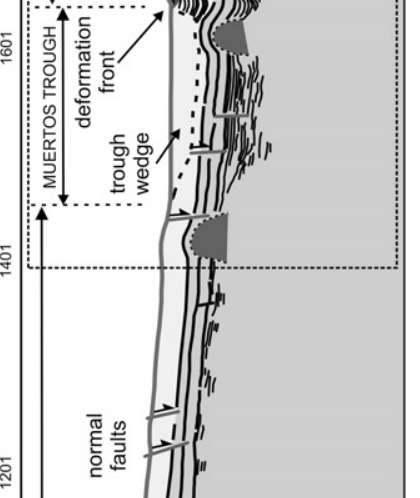

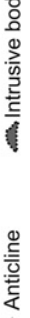

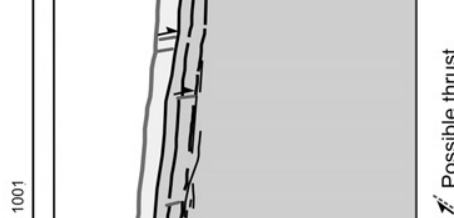

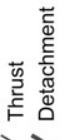

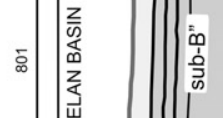

AN

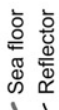

11

Б

总

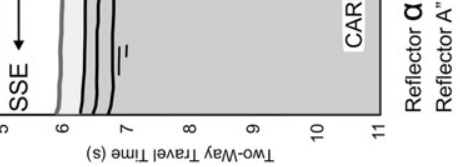


J.L. Granja Bruña et al. / Marine Geology 263 (2009) 7-33
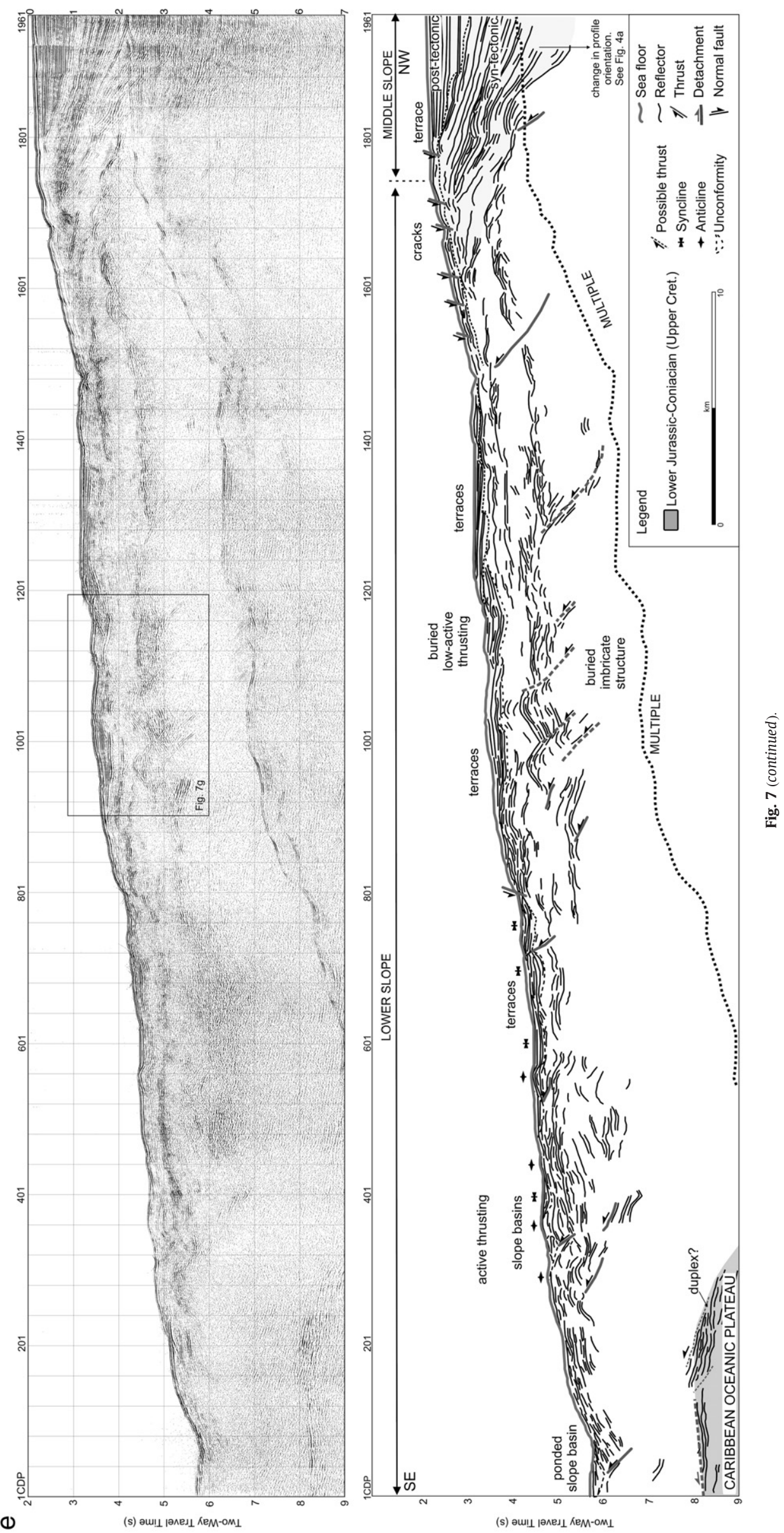

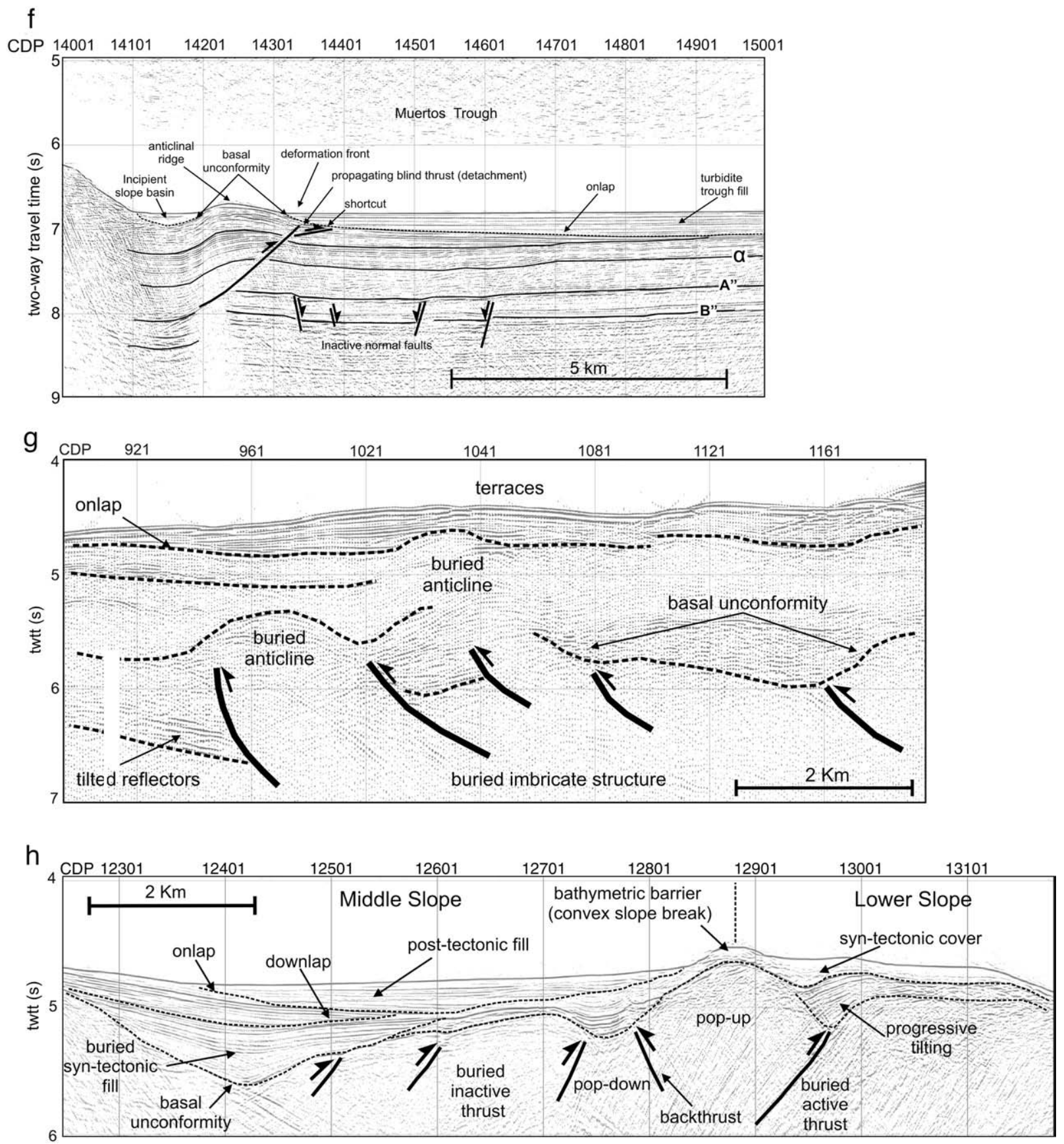

Fig. 7 (continued).

mechanical behavior of the basalts and the Carib beds. However, we cannot reject the possibility of accretion of basement rocks of the Caribbean plateau (layers below $\mathrm{B}^{\prime \prime}$ reflector) in the inner parts of the thrust belt (Fig. 7e).

The northern boundary of the trough is clearly defined by the toe of the steep insular slope, essentially coincident with the deformation front (Figs. 3b, c; 4a, b, c). Locally, small frontal structures appear located forward of the main deformation front (Fig. 7f). The boundary between the trough and the Venezuelan Basin, on the other hand, shows high lateral variability (Fig. 4c). In the eastern part, between $67.7^{\circ} \mathrm{W}$ and the multibeam data end $\left(66.5^{\circ} \mathrm{W}\right)$, there is no distinct morphological trough possibly due to a higher sediment supply in this region (Fig. 3c). Here the turbidite wedge is much wider and thicker, and continues southwards outside of the multibeam and seismic data coverage (Fig. 7a). The satellite-derived bathymetry shows the
$-5000 \mathrm{~m}$ isobath occupying a broader zone southwards in this region (Fig. 1). The horizontal reflectors define different sequences of turbidite fill in the trough onlaping the gentle northward dipping Venezuelan Basin layers. Between $68^{\circ} \mathrm{W}$ and $67.7^{\circ} \mathrm{W}$ there may be no turbidite wedge and the Venezuelan Basin is in contact with the deformation front (AUF in Fig. 4b). In the area located between $67.8^{\circ} \mathrm{W}$ and $70^{\circ} \mathrm{W}$, the southern margin of the trough is characterized by fault scarps marking a clear boundary between the flat seafloor of the trough wedge and the gentle northward slope of the Venezuelan Basin (Figs. 3b, c; 4b,c; 5).

On the basis of morphological and structural criteria, we have divided the Muertos Trough into two segments separated by a zone of relatively higher east-west bathymetric gradient $\left(\sim 0.6^{\circ}\right)$ located between $68^{\circ} \mathrm{W}$ and $67.7^{\circ} \mathrm{W}$ (Figs. 4a, 6c): a shallower eastern trough (average depth $-5220 \mathrm{~m}$ ) and a deeper western trough (average 
depth $-5550 \mathrm{~m}$ ). The $300 \mathrm{~m}$ of difference in depth between the two segments is formed by the combined offset of several fault scarps, which obliquely cut the trough (Figs. 3b, 4b).

\subsubsection{Western trough}

The western segment is an elongated morphological expression, a flat seafloor and is the deepest area of the Muertos Trough (Figs. 3b, 4a, 6c). This segment is confined to the south (outer wall) by scarps sub-parallel to the deformation front resulting in a structurally ponded basin (Figs. 3, 4c, 5b; 7c, d). The width of the confined trough is variable, but it becomes narrower and shallower eastward from $68.5^{\circ} \mathrm{W}$ until it disappears about $68^{\circ} \mathrm{W}$ (AUF in Fig. 4b). Eastward of $68.5^{\circ} \mathrm{W}$ fault scarps are progressively oriented north-eastward and lie obliquely to the deformation front yielding a zone of relatively higher bathymetric gradient in the trough axis. Moreover fault strands seem to converge and disappear beneath the deformation front (AUF in Fig. 4b).

The scarps are the result of the activity of normal faults (Fig. 7c, d). The faults are only observable in the Venezuelan Basin near the trough and beneath the turbitide wedge. Although they may continue below the detachment surface, they are not observable in the seismic profiles (Fig. 7c, d). They affect the sedimentary cover (Carib beds) and top of the basement ( $\mathrm{B}^{\prime \prime}$ reflector) and seem to be largest within the trough. These normal faults create northward dipping scarps on the seafloor with slopes between $3^{\circ}$ and $8^{\circ}$ (Fig. 5a) and produce offsets of 0.2 to $0.1 \mathrm{~s}$ (twtt) in the seismic reflectors of the Carib beds (Fig. 7c, d). A monoclinal ridge is observed locally inside the trough. This ridge is formed above a southward-dipping normal fault that has deformed the surrounding flat-lying sediments of the turbidite wedge (Fig. 7c).

\subsubsection{Eastern trough}

The eastern segment shows a smooth topographic undulation of the seafloor without a distinct morphological trough (Figs. 3a, c; 4a, c; $6 c)$. However, further east outside our study area (eastwards of $66.5^{\circ} \mathrm{W}$ ), Matthews and Holcombe (1974) from reflection profiles and Masson and Scanlon (1991) from GLORIA side-scan sonar data interpreted one fault scarp sub-parallel to the deformation front. We only observe a very gentle bathymetric variation from the toe of deformation front $30 \mathrm{~km}$ south toward the Venezuelan Basin (Figs. 4c, 7a). Seismic profile 1292 (Fig. 7a) and the adjoining profile to the south (Driscoll and Diebold, 1999) also show the eastern trough without normal faults in the outer wall of the trough unlike the western trough (Fig. 4c).

Both seismic and multibeam data show one anticline forward of the main deformation front which is forming a small ridge subparallel to the deformation front (Figs. 7f, 9). This feature has an elongate shape as a consequence of the activity of a propagating blind thrust, which is folding the trough fill. This thrust is the result of the propagation of the detachment surface toward the turbidite wedge, but it is buried by horizontal turbidite layers suggesting a low rate of recent activity.

\subsubsection{Intrusive bodies}

Many seamounts and volcanic bodies have been documented in the Venezuelan Basin region (i. e., foreland) from GLORIA side-scan sonar, seismic profiles and geomagnetic data (Donnelly, 1973; Matthews and Holcombe, 1985; Jany, 1989; Driscoll and Diebold, 1999; Mauffret and Leroy, 1999). These bodies frequently deform the seafloor and have been interpreted as intrusive bodies. We have identified in one seismic profile several intrusive bodies in the trough region and beneath the thrust belt which disrupt the normal continuity of the Carib beds and indeed deform the seafloor (Fig. 7d). These bodies may play an important role in the pattern of the thrust belt because they can damage the imbricate structure (Dominguez et al., 2000; Marques and Cobbold, 2002). Multibeam bathymetry data show a conical feature $100 \mathrm{~m}$ higher than the seafloor at $67.7^{\circ} \mathrm{W}$ and $17.2^{\circ} \mathrm{N}$ (see volcanic body in Fig. 4b). This coneshaped feature could be interpreted as being of igneous origin, but with our data we cannot reject a possible mud diapir origin which is frequently observed in convergent margins (e.g., Barbados; Brown and Westbrook, 1987).

\subsection{Lower slope}

The lower slope is situated at the base of the insular slope, from the toe of the deformation front to the convex slope break (Figs. 4, 6a, b). It has a width of $45 \mathrm{~km}$ in the western part (from $68.6^{\circ} \mathrm{W}$ westwards), and becomes narrower eastward, being only $14 \mathrm{~km}$ wide at $66.5^{\circ} \mathrm{W}$ (Fig. 4b).

The lower slope angle is $4^{\circ}$ to $9^{\circ}$. Locally, the slope gradient exceeds $20^{\circ}$ corresponding to structural ridges (Figs. 3, 5a). Anticlinal ridges are steep and narrow, and are sub-parallel to the deformation front (Figs. 3b, c; 4b). They have an asymmetrical cross-section where the landward slope is less steep than the seaward slope (i.e., southward vergence; Figs. 3, 4c, 6a, b). Ridges can rarely be traced for more than $30 \mathrm{~km}$ along strike (Fig. 4b), perhaps as a result of segmentation by transverse faulting or because of their own imbricate architecture (anastomosing). Ridge spacing varies along the unit, but it appears shorter near the deformation front (about 1-2 km), and longer ( $4 \mathrm{~km}$ ) on the higher slope (Fig. 3b, c). This increase in ridge spacing is also related to the increasing size and continuity of ridges higher on the slope.

Normally, small elongate slope basins and terraces occupy the troughs between the adjacent imbricate thrust slices (Figs. 4b, 7e, g), but in some cases they can reach much bigger sizes $(25 \times 2.5 \mathrm{~km}$; see $B$ in Fig. 4b). We use the expression "terraces" to refer to over-filled slope basins with gentle slopes which cover the insular slope and bury the structure (seismic profile vb-2n is oblique to the deformation front and therefore, it does not provide a suitable transversal cross section (Fig. 7c, g)). These types of basins, which are associated with thrust sheets, are called piggy-back basins in subaerial settings and trenchslope basins in submarine settings (Charvet and Ogawa, 1994). We use the name "slope basin" to avoid the implication that a subduction process is taking place in the Muertos margin which is still controversial. As a result of the differential activity of thrust slices, these basins are characterized by sediment fill tilted to a greater or lesser extent (Fig. $7 \mathrm{~g}$ ). The imbricate structure in some places causes ponded basins, which only receive local sediment supply (isolated or immature slope basins; Mutti and Ricci Lucchi, 1978), and not the channelized turbiditic currents from the upper slope (mature slope basins) (Fig. 7b). When sedimentation rate is faster than the thrusting activity, the slope basins are completely filled giving rise to terraces. Terraces smooth the slope and are associated with shallower horizontal and smooth downward dipping sedimentary reflectors (Fig. 7g).

Seismic records show the continuation of Carib beds beneath the insular slope, but they only give limited information about the internal structure of the thrust belt (Fig. 7a, c, d). Seismic images do not show many coherent reflections in the overlying folded sediments, perhaps due to a high degree of deformation (i.e., tectonic melange) and in some cases also due to the poor quality of the seismic record. However, many synthetic imbricate thrust planes associated with slope basins and anticlinal ridges can be inferred (Fig. 7a, c, d, e, g). These fault planes are mainly northward dipping and are synthetic with the detachment surface. Locally, there are some backthrusts related to the convex slope break, but they are buried by slope sediments and seem to be secondary features in the observed morphostructure (see pop-up in Fig. 7h).

By analogy with other deformed belts (e.g., North Panama Deformed Belt; Silver et al., 1995) and accretionary prisms (e.g., Barbados, Brown and Westbrook, 1987; Makran; Kopp et al., 2000 and 
a

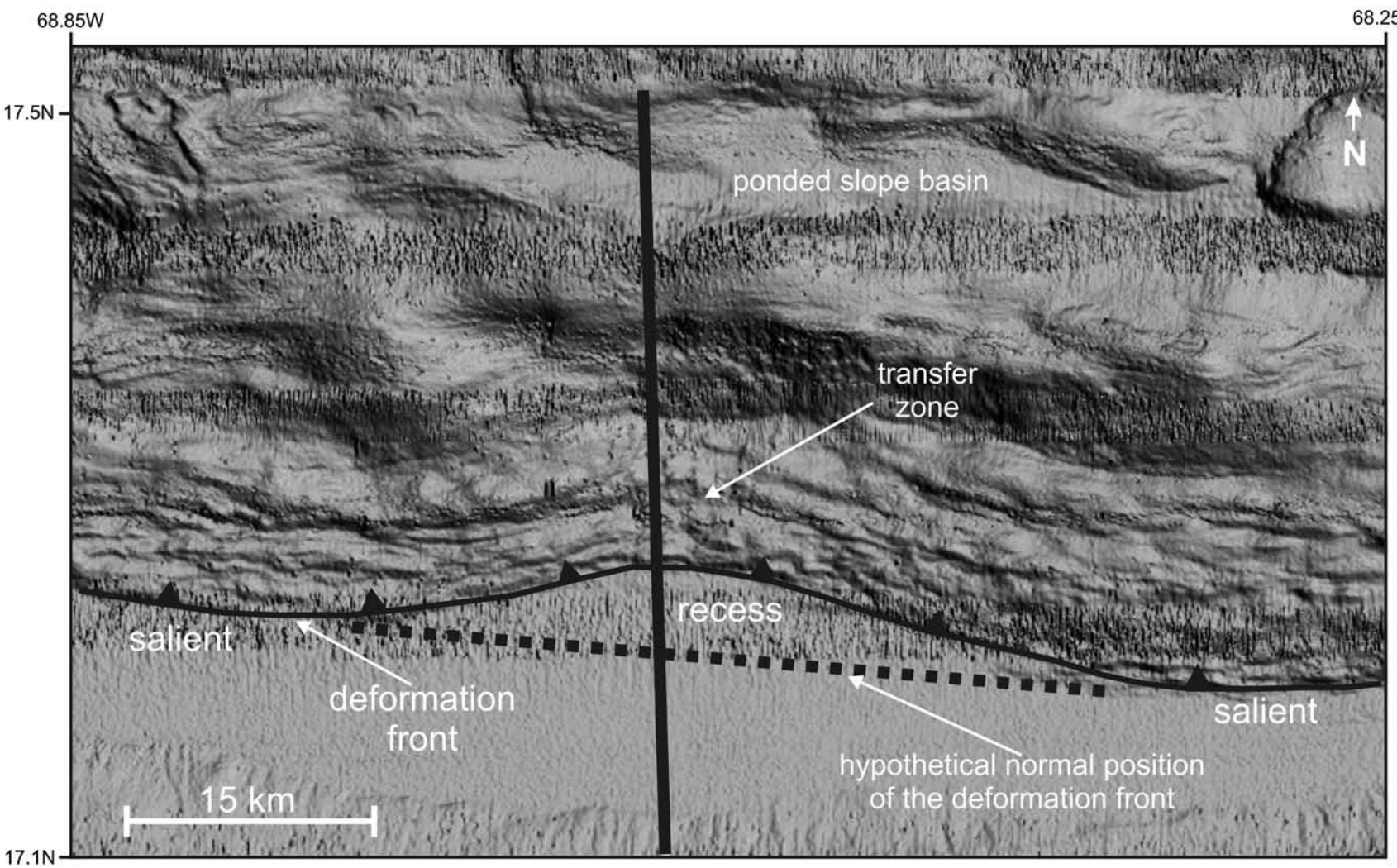

b

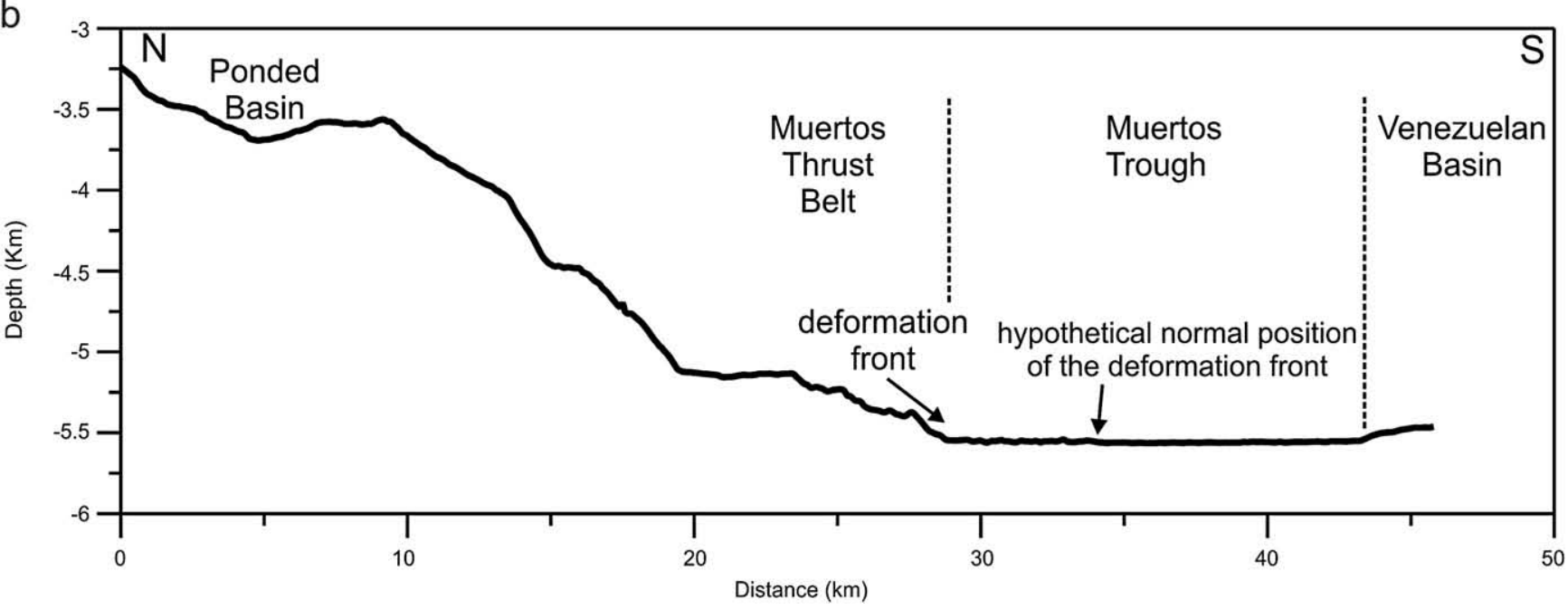

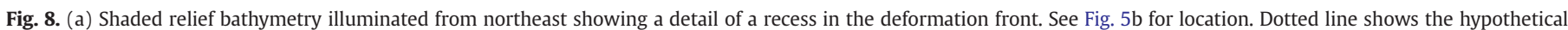
normal position of the deformation front. (b) North-south bathymetric profile across the recess zone. See Fig. 8a for profile location.

Kukoswki et al., 2001), the lower slope corresponds with the more active area of compressive deformation, and with the initial accretion process (Figs. 4b, 7e). Part or all of the sequence of pelagic, hemipelagic and turbiditic sediments located in the foreland area (trough wedge and Carib beds) are offscraped and accreted forming a sequence of numerous imbricate thrust slices.

We have identified several fault zones or shear zones trending transverse to the deformation front in the multibeam bathymetry data (TZ in Fig. 4b). These fault zones begin at the toe of the deformation front and some of them are associated with recesses in the deformation front (Marshak, 2004; Ruled areas in Fig. 4a). These recesses imply a landward retreat of the toe of the deformation front (from a hypothetical "normal" position), which reaches $6 \mathrm{~km}$ in some of them (Fig. 8). Most of these fault zones can only be observed on the lower slope, deforming the anastomosing fabric of the imbricate structure. Only one of the faults continues upward and is possibly associated with a big drainage system in the upper and middle slope (See DS in Fig. 4b; Fig. 9). Along these zones the east-west trending fabric of the accretionary complex is faulted and segmented by the interference of oblique and lateral thrust ramps yielding transfer or accommodation zones.

\subsection{Middle slope}

The middle slope extends from the convex slope break to the concave slope break (Figs. 4a, c; 6a, b). In many places the concave slope break is not well defined by the multibeam bathymetry data because the sedimentation rate may be higher than the deformation 


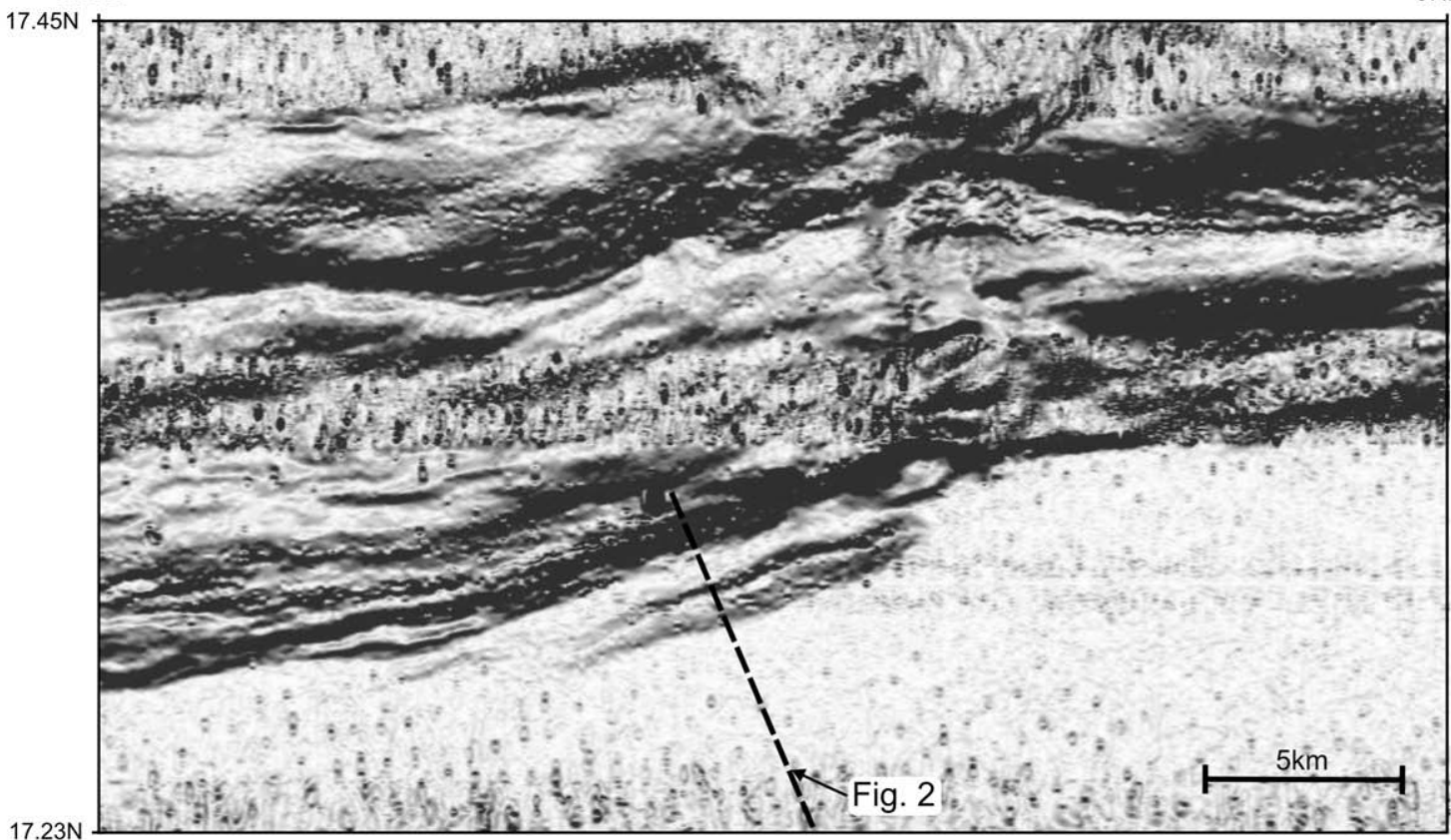

b

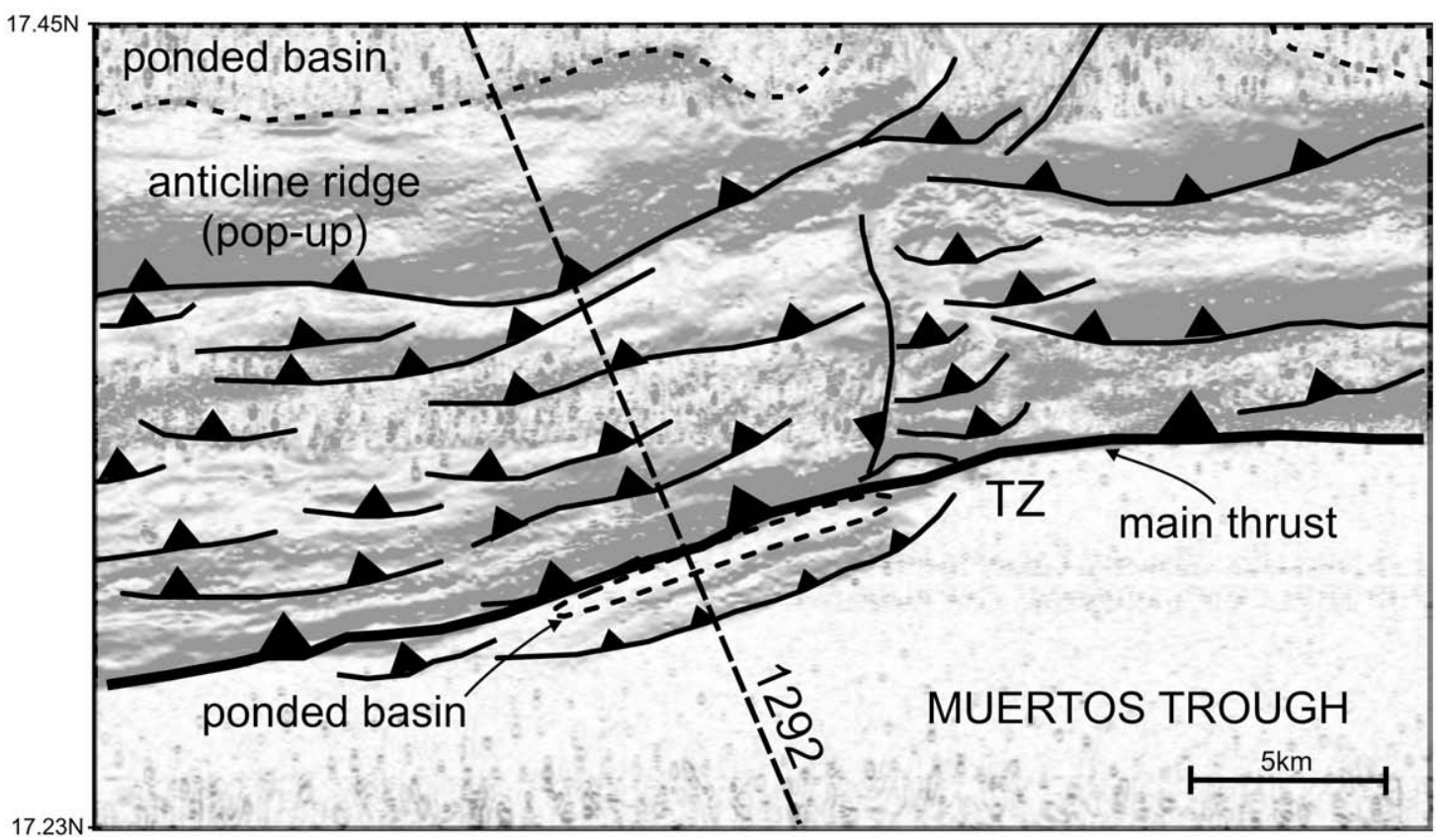

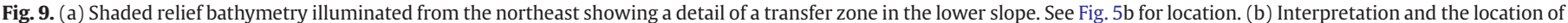
the seismic profile 1292 (Fig. 7a, f). TZ = Transfer Zone.

rate, resulting in smooth bathymetric profile. Therefore, structural (e.g., degree of thrusting activity or the presence of normal faults) and sedimentary (e.g., mass movements) criteria are more useful to constrain the boundary between these slopes.

The middle slope is also characterized by an imbricate structure similar to the lower slope (Fig. 4b, c), but here the structure is buried in most places by extended slope deposits (Figs. 5a, 7b). This buried structure could be due to lower thrusting activity and/or to a higher sedimentation rate. Although the middle slope has a smoother morphology than the lower slope, some ridges reach slopes of $7^{\circ}$ (Fig. 5a). The sediments in the middle slope have accumulated in bigger ponded slope basins and terraces. Their map-view shape is irregular unlike the elongate basins of the lower slope (Fig. 4b). Most basins show connection with the drainage network of the upper slope
(Fig. 5b); hence, they must play an important role in the trapping of turbiditic flows from source areas in the higher slope and onshore areas (Forsthoff and Holcombe, 1983). The thickness and the width of the slope basins and terraces are highly dependent on the basin location with respect to the turbiditic supply and the degree of thrusting activity (Fig. 5b). In the middle slope, the thickness of the slope deposits is variable, with an average of several hundreds meters (Fig. 7a, b, f). One exception is the slope basin/terrace that appears in the upper western corner of the survey area which shows more than $2 \mathrm{~s}$ (twtt) of sediment fill $(\sim 2000 \mathrm{~m})$, with a syn-tectonic and a post-tectonic sequence (See $\mathrm{X}$ in Figs. 4b, 7e). Ponded basins show an asymmetrical cross-section, with the landward wall steeper than the seaward wall, which is characteristic of the troughs formed inside imbricate structures (Moore and Karig, 


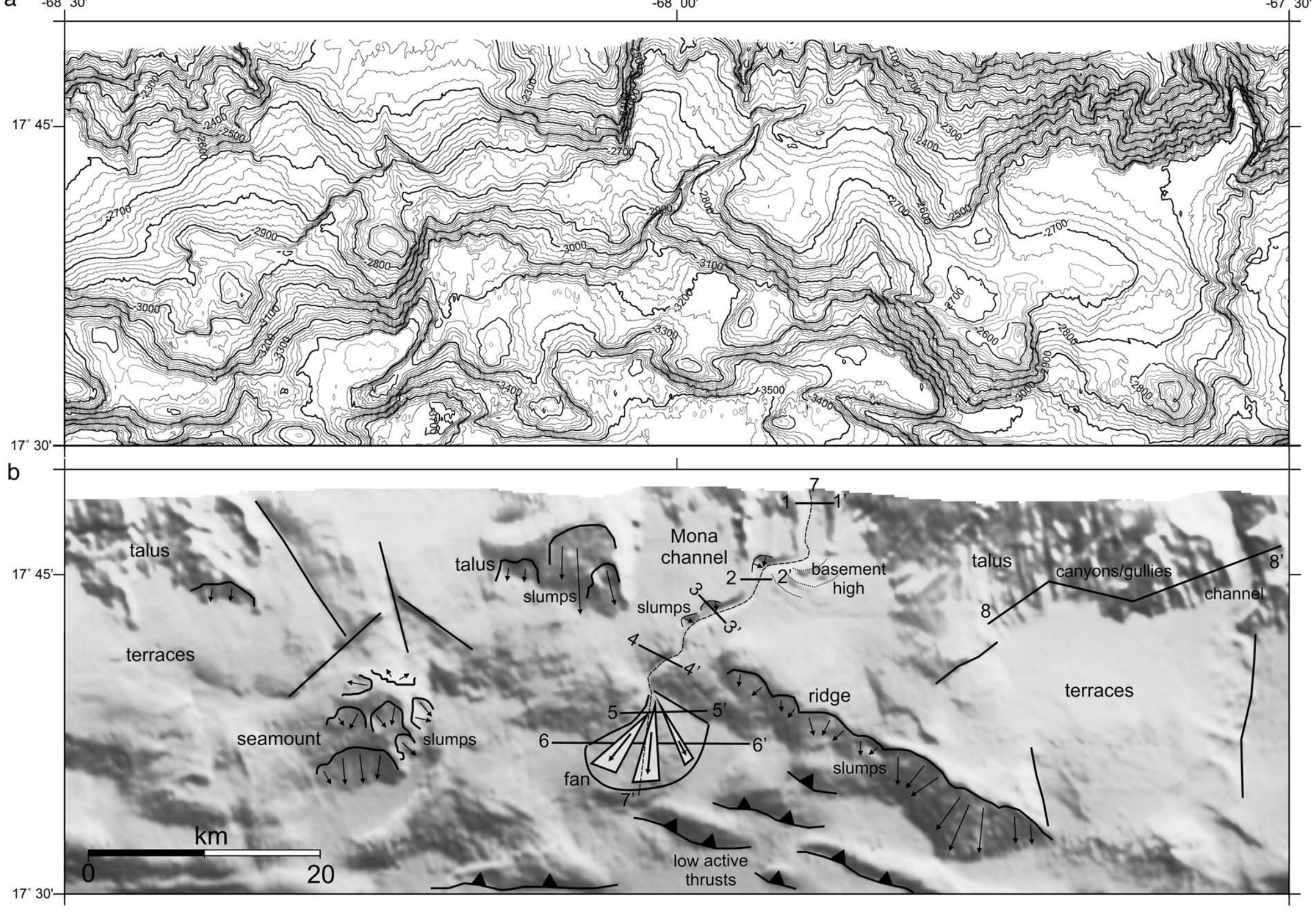

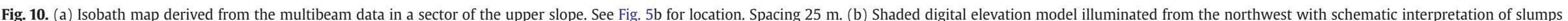
associated with seamount, talus and ridges. Note Mona Channel and a fan. Numbered lines - locations of bathymetric profiles shown in Fig. 10c. See Fig. 5b for location. (c) Bathymetric profiles located in Fig. 10b. T = Thalweg. 
C
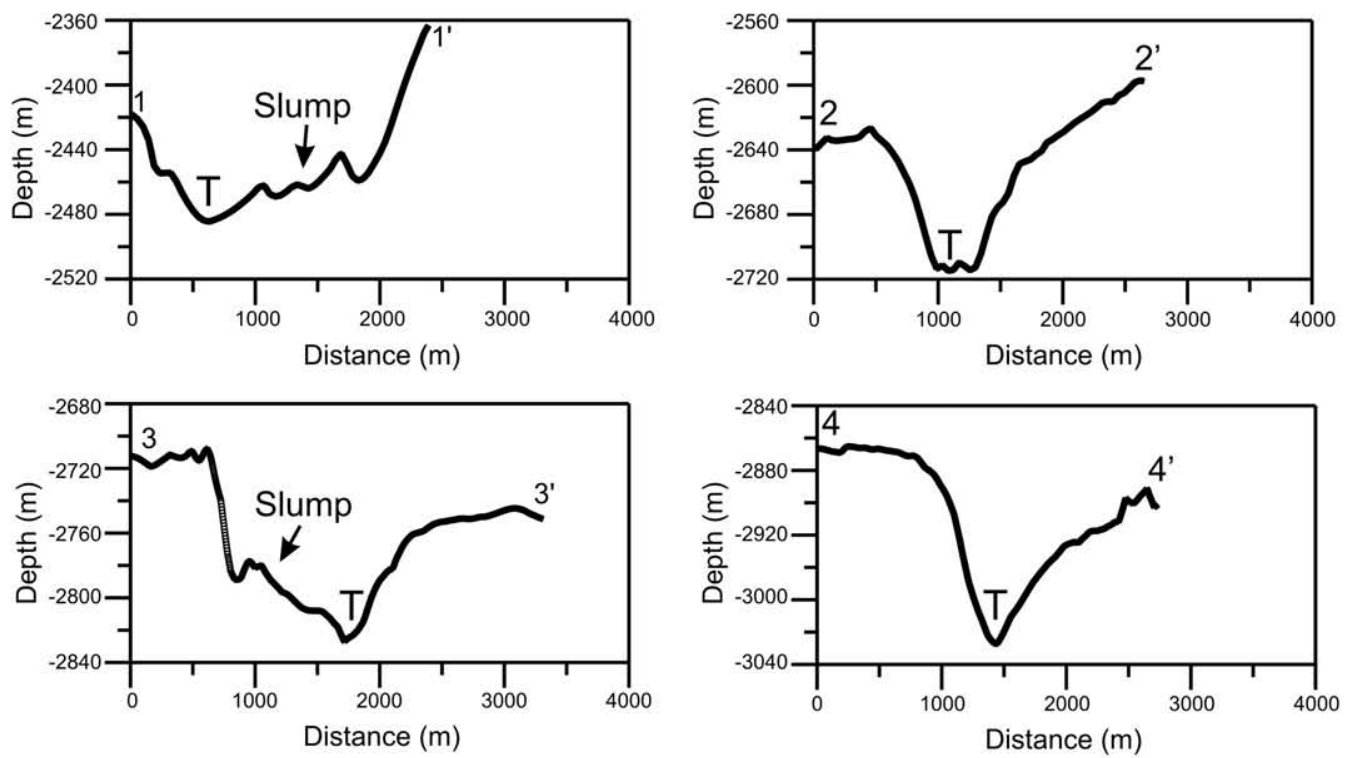
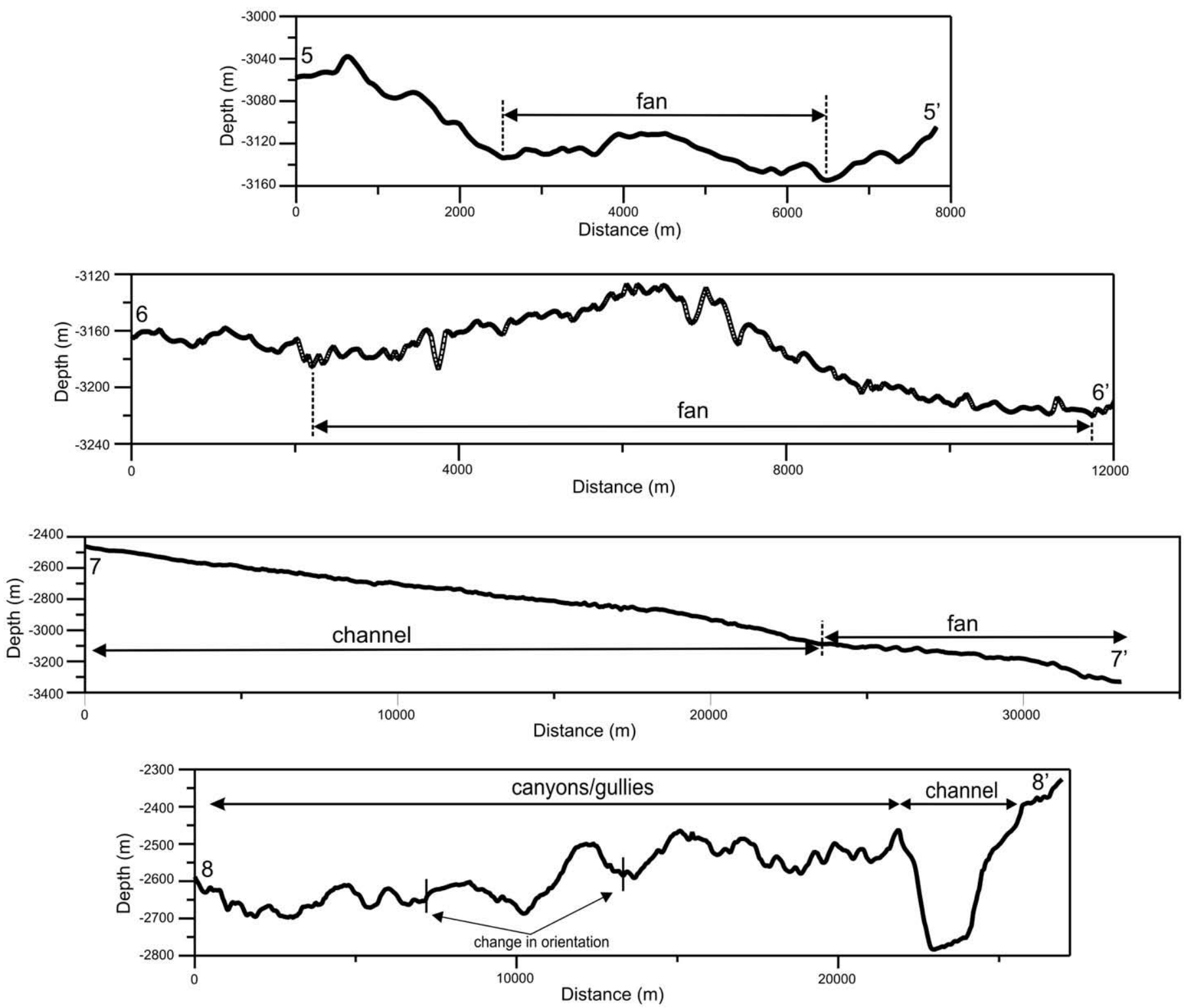

Fig. 10 (continued) 
1976; Scholl et al., 1980; Charvet and Ogawa, 1994). Bigger slope basins show deeper sedimentary layers tilted as a result of syntectonic sedimentation, while sub-horizontal shallower reflectors have been deposited in a posterior stage of lower tectonic activity (Fig. 7b, g).

Such a process is taking place in the lower slope, but in the initial stages of the accretion process. Slope basins begin to form at the base of the lower slope where the sediments are ponded between adjacent ridges. The slope basins show a progressive increase in width from 2 or $3 \mathrm{~km}$ to more than $10 \mathrm{~km}$ in the middle slope (Fig. 7a, b, g). This increase in size would be a consequence of the addition of more accreted material, which causes uplift and rotation of thrust planes together with the overlying slope sediments (Fig. 7b). As deformation continues, motion along some thrust faults dies out, and the inactive thrusts become buried by slope sediments, thus increasing the size of slope basins (Moore and Karig, 1976; Scholl et al., 1980).

Most thrust lineaments are sub-parallel to the deformation front suggesting a thrust component origin similar to the actual north-south compression regime observable in the structure of the lower slope (Fig. 4b). Locally, structural lineaments are obliquely oriented $\left(110^{\circ}\right)$ with respect to the deformation front $\left(090^{\circ}\right)$, and there are even a few perpendicular lineaments (north-south and northeast-southwest trending) (Fig. 4b). These changes in orientation together with the variable lateral development (i.e., number of thrust slices) of the thrust belt could represent changes in the convergence vector in previous stages of the accretion process.

\subsection{Upper slope}

The upper slope extends from the concave slope break up to the edge of the platform, situated at the top of the island arc (see extension of carbonate platform in Fig. 1; Fig. 7b). It is characterized by the talus derived from the carbonate platform and also by the presence of extensive terraces with gentle seaward slopes (Figs. 4c, $5 a)$. We use the expression "talus" or "talus region" to refer to the steeply-sloping area between the platform or terraces (flat or gentlysloping areas) and the terrace deposits (gently sloping areas) located at the base of that steeply-sloping area (see talus in Fig. 5a) Sedimentary processes, such as mass movements and gravity flows are important here, yielding a smoother bathymetry. Thicker slope deposits cover almost totally the imbricate structure and the island arc basement (Fig. 7a, b). In general structural lineaments do not show a clear relation to the structures of the middle and lower slopes (Fig. 4b). Lineaments in the upper slope are straight unlike those downslope (arcuate) which could reflect a different tectonic regime and also the presence of the carbonate platform talus.

In the upper slope, slumping and sliding are very important processes (Fig. 4b). Many slumped areas are aligned following the scarps or ridges (Fig. 10b). However, some areas near isolated hills or high slopes in the talus area may also be controlled by lithologic parameters such as less consolidated materials.

\subsubsection{Terraces}

Terraces occupy much of the extended regions immediately south of the toe of the talus, with slopes between $0.5^{\circ}$ and $5^{\circ}$, and end downwards in a more or less marked scarp or simply in a smooth convex slope break (Figs. 4c, 5a). The internal structure of the biggest terraces comprises more than $1 \mathrm{~s}$ (twtt) of thickness of continuous sediment layers (Fig. 7a; See Yuma Basin in Fig. 7b). Terrace deposits bury old ponded basins, an inactive imbricate structure or an acoustic basement. The deeper structure of the upper slope, where observable, could show a more evolved stage of the accretion process which is no longer active and the basement of the island arc (Fig. 7a). On the other hand, sedimentary processes play a much more important role in burying and smoothing the morphostructure. Frequently, the terraces are associated with normal faults (Fig. 7a, b). These normal faults would be related to the extensional regime documented in the carbonate platform (van Gestel et al., 1998; Mann et al., 2005; Grindlay et al., 2005).

\subsubsection{Talus region and drainage network}

Multibeam bathymetry data show only the lower part of the talus region in the central and eastern areas of the surveyed zone (Figs. 5a, $4 \mathrm{~b})$. Possibly in the western region the talus is located higher in the slope, or there is simply no talus (Fig. 7b). The talus regions are characterized by slopes between $4^{\circ}$ and $7^{\circ}$, reaching $>15^{\circ}$ in areas associated with a complex and dense drainage network, composed of gullies, canyons and channels (Fig. 5a, b). We use the expression "canyon" to refer to a deep, steep-sided valley cut in the talus region and with an axial slope $>80 \mathrm{~m} / \mathrm{km}$ (Allaby, 2008). Channels have smaller slope angles and are mainly associated with the terrace areas. Turbidite currents flow down along this drainage network and transport material southward from the carbonate platform and the onshore areas (e. g., Hispaniola and Puerto Rico islands). This transported sediment is deposited along the insular slope forming the terraces and slope basins (Fig. $4 \mathrm{~b}$ ). Most gullies/canyons are only observable along the talus and fade away when they reach the basins and the terraces at the toe of talus. This fact suggests that most of the sediment load is deposited there and only a minor amount reaches the downslope basins or the Muertos Trough (Figs. 4b, 5b).

Locally where many canyons/gullies come together they form bigger channels that flow along the slope deposits and reach the middle slope (Fig. 4b). The most developed canyon system in the south slope of Puerto Rico appears to be the Guayanilla Canyon system (GC in Figs. 5b, 11). This system is connected with onshore rivers and shows an incisive valley in the talus, but it only reaches the upper slope terraces. However, high reflectivity observed in the GLORIA sidescan image shows continuity between the canyon and the trough, indicating that turbidites may reach the trough (Masson and Scanlon, 1991). A through-flow of turbidites from Puerto Rico to the eastern trough may explain the thicker sediment fill of the eastern trough relative to the western trough and the absence of a distinct morphological trough there. Here the distance between the island and the trough is only $70 \mathrm{~km}$ and the average slope is higher $\left(4^{\circ}-5^{\circ}\right)$ than in other places of the insular slope. Turbidite currents may therefore be able to reach the trough, although they are not channelized.

We have selected a representative region of the upper slope for a more detailed analysis of the channel network (Fig. 10). Multibeam bathymetry data show a big channel flowing from the Mona Passage area ( $\mathrm{CH}$ in Fig. 4b). This channel was identified previously in the GLORIA backscatter mosaic (Masson and Scanlon, 1991). We propose that this channel be named Mona Channel. The Mona Channel flows from north to south in the talus and changes to southwestward over a terrace possibly conditioned by basement highs. It shows a smooth sinuosity $(1.09=$ channel length/channel reach length) bordered by slumped flanks (Fig. 10b). Bathymetric profiles across the channel show a wide and scarped valley with a $\mathrm{V}$-shaped section suggesting an actual process of erosion (profiles 1-4). Profiles 1 and 3 show that slumping process are frequent in the flanks. This channel flows into a well-developed fan, occupying an area of about $40 \mathrm{~km}^{2}$ (Fig. 10b). Along profile 7 a smooth concave slope break separates the channel areas where erosion is active from the fan areas where deposition dominates. The bathymetric profiles across the fan show a convex cross-section with a dense distributary network. Several incisive Vshaped canyons could be more active flow line (profiles 5-6). Profile 8 compares between two distinctive process taking places in the talus. The V-shaped cross-section of the canyons and gullies indicates actual erosion, while the U-shaped cross-section of the channel indicates active sedimentation. This channel shows a deep and wide valley which becomes faded when it abandons the talus region and enters the terrace areas. Here there is no fan; sedimentation takes place 


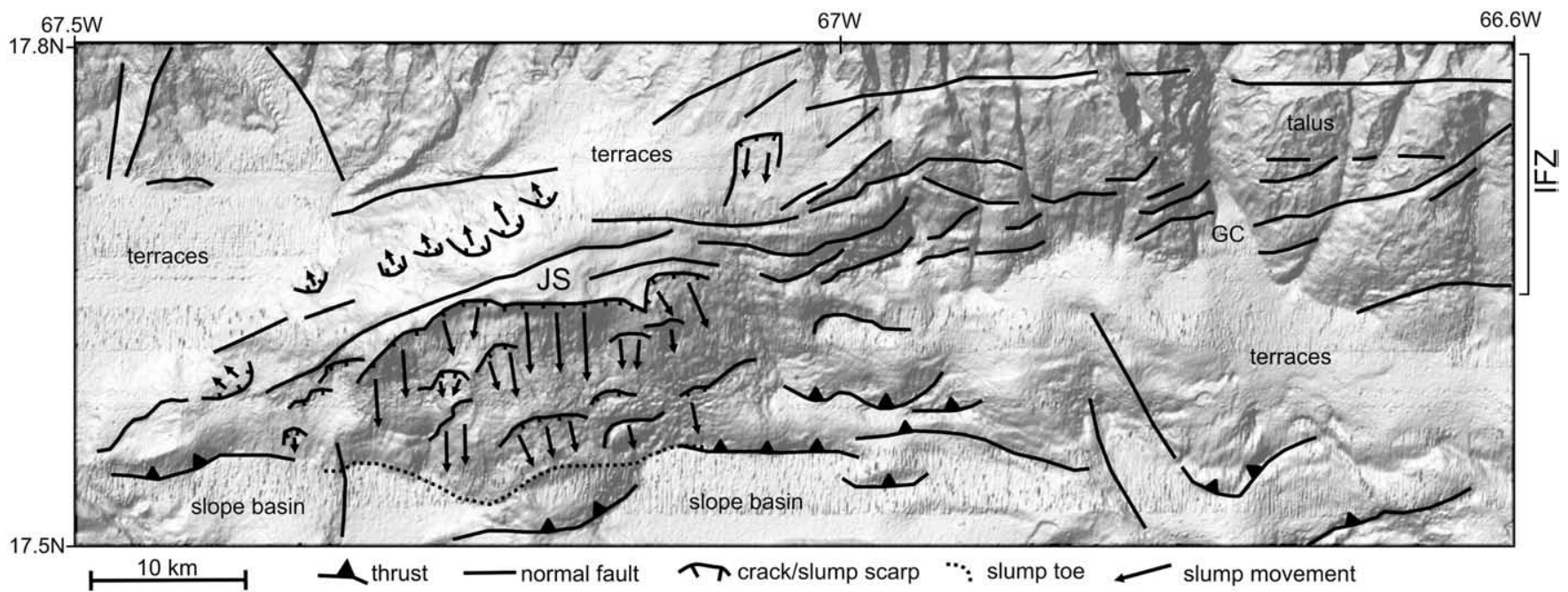

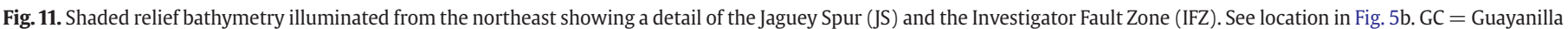
Canyon System.

along the seafloor of the valley. Due to the considerable size of these channels, they can reach the middle slope and play an important role in transporting downslope significant load of turbidite, developing the observed extended slope basins and terraces.

\subsubsection{Surface expression of the investigator fault zone}

In the offshore areas to the south and southwest of Puerto Rico, we have identified the western end of the Investigator Fault Zone (IFZ in Fig. 1; Case and Holcombe, 1980; Garrison, 1972). Here the fault zone is oriented northeast-southwest turning more east-west farther east (IFZ in Fig. 4b, 11; Fig. 5b). This fault zone is composed of several strands which yield steps and flats in the talus slope (Figs. 5b, 6b). The main strand is located higher in the slope and its straight trace suggests a sub-vertical fault plane. Canyons vary their orientation locally adapting to the vertical step faults (Fig. 11). Faults do not yield lateral offsets in the canyons, which thus eliminates a possible active strike-slip component as previously suggested by van Gestel et al (1998) and Mann et al (2005). This fault zone disappears westwards beneath the thick terrace deposits and the imbricate structure of the middle slope about $67.3^{\circ} \mathrm{W}$. A bathymetric high, named Jaguey Spur (JS in Figs. 1, 4a, 11) is observed at the western end of the Investigator Fault Zone (Case and Holcombe, 1980). This bathymetric feature does not fit our slope classification, but it may show more affinity with the upper slope. Moreover, this bathymetric high is associated with Bouguer and geomagnetic anomalies and is therefore probably different from the rest of the upper slope (Granja Bruña et al., 2008; Catalán et al., 2008). The top and the north side of this bathymetric high is crossed by several strands of the Investigator fault zone. Here these faults show evidence of recent activity that could contribute to the slope instability in a wide area north and south of the Jaguey Spur, where a large area of slumping can be mapped (Fig. 11).

\section{Discussion}

\subsection{Normal faults in the foreland}

Forsthoff and Holcombe (1983) proposed that the bathymetric scarps in the foreland are a result of major subsidence as a consequence of major turbidite accumulation. However, seismic profiles do not support this proposal, because in the eastern trough (Fig. 7a) the thickness of the trough wedge is larger than in the confined western though (Fig. 7c, d). Therefore, sediment accumulation at different rates along the trough does not have a significant effect on the subsidence and normal fault development in the western half of the trough.

In principle we could distinguish between preexisting and new structures in the underthrusted plate or foreland areas by means of their orientation. Essentially, faults related to the dominant compressional process observed in the margin have to have parallel or subparallel orientation to the deformation front; whereas pre-existing faults need to bear no obvious relationship to the trend of the margin (Lallemand et al., 1986). In the Muertos margin the normal faults observed in the foreland area are sub-parallel to the margin (Fig. 4b). This fact and the proximity of the scarps to the deformation front $(<30 \mathrm{~km})$ indicate activity related to the thrusting process, and possibly reactivated from an earlier oceanic fabric (Figs. 3b; 4b; Ranero et al., 2005). Other seismic surveys carried out in the Venezuelan Basin's interior show inactive normal faults trending NE-SW (e. g., Central Venezuelan Fault Zone). These faults essentially affect the basement (Driscoll and Diebold, 1999) and they do not have similar orientation to the ones observed in the proximity of the Muertos margin. Similar Normal faults with orientation sub-parallel to the southern margin of the Venezuelan Basin have also been documented (Ladd and Watkins, 1978), where a similar thrusting process also takes place.

Generally the sub-parallel normal faulting in the outer wall of troughs/trenches is known as horst and graben chain-saw model (Hilde, 1983). This model is commonly associated with two hypotheses for the origin of these faults: the downward flexing (elastic bending) of the underthrusted plate due to slab pull or/and the overburden (lithostatic load) of accretionary prism/thrust belt material over the overridden plate (Charvet and Ogawa, 1994).

The downward flexing of the underthrusted oceanic crust as a result of the slab pull also generates an outer swell and an extensional regime in the seafloor seaward the deformation front (Charvet and Ogawa, 1994). The Venezuelan Basin crust shows a smooth bending with the axis located about the center of the Basin (Driscoll and Diebold, 1999). There is not an active extensional regime at the axis of the bending despite the predicted maximum curvature there. This fact could be related to a thick crust in this region, which does not bend readily; Moreover, the curvature is quite uniform and does not increase in the north and south margin areas where the normal faults appear (Ladd and Watkins, 1978). Therefore, a slab pull caused by a well developed subducting slab does not seem to be a determinant cause for yielding the observed extensional regime in the foreland area of the Muertos margin. Normal faults observed in the foreland area mainly coincide with western trough region, where the thrust 
belt (essentially lower and middle slopes) is wider (Fig. 4b, c). We suggest that the more probable reason for the normal faulting subparallel and close to the margin only in the western trough could be the larger load of accreted material over the thrusted plate south of the Dominican Republic.

\subsection{Turbidite supply to the central Muertos Trough}

Except for the central zone of higher bathymetric gradient, the Muertos Trough has a very smooth seafloor, and is flat in the western trough. This could be due to a high sedimentation rate that inhibits the deformational rate of the margin, as well as to the redistribution of the sediments by sea bottom currents, which level the seafloor morphology. In principle the turbidite supply to the Muertos trough comes from the Venezuelan Basin region, along the trough axis and from the insular slope.

The supply from the Venezuelan basin is likely to be relatively minor, however, since there are no onshore areas in the region. Forsthoff and Holcombe (1983) suggested an important east-to-west turbidite flow along the trough axis. ten Brink et al. (in press) mapped west-facing sand waves at the eastern end of Muertos Trough, which suggest sediment supply coming from the gap between St. Croix island and Aves Ridge. This sediment supply may be carried by an intermediate-depth current flowing from the Atlantic Ocean to the Caribbean Sea via Anegada Passage. The trough axis shows a smooth gradient from east to west. The final area of sediment accumulation is located in the deeper western trough, but there the trough wedge of sediments is less thick. The seismic profile located in eastern trough, shows an unconfined trough wedge with $1.25 \mathrm{~s}$ (twtt) of sedimentary thickness at the trough axis (thickness estimated between the $\mathrm{A}^{\prime \prime}$ reflector and the seafloor) (Fig. 7a). On the other hand, the seismic profiles located in the confined western trough show $0.87 \mathrm{~s}$ and $0.83 \mathrm{~s}$ (twtt) respectively of sedimentary thickness (Fig. 7c, d). Therefore, the turbidite flow along the trough axis is not very effective in reaching the western part of the trough. This east to west flow could be restricted in the region where normal faults cross the trough $\left(67.7^{\circ}-68^{\circ} \mathrm{W}\right)$.

The main turbidite supply to the central Muertos Trough comes from the onshore areas and the carbonate platform along the insular slope. Seismic data from the eastern trough show a significantly wider and thicker trough wedge than observed in the western trough. The eastern trough is located essentially along the south coast of Puerto Rico. Here the insular slope has a higher slope on average and the distance between the island/carbonate platform and the trough is shorter $(60-70 \mathrm{~km})$, compared with the slope south of Mona Passage and the Dominican Republic. The talus occupies a wider zone of the upper slope and there is a dense and well-developed drainage network (e. g., Guayanilla Canyon). In addition, the thrust belt is relatively thin $(\sim 25 \mathrm{~km})$, and therefore has fewer sediment traps and bathymetric barriers. All these factors allow more turbidites to reach the trough resulting in a bigger trough wedge and the lack of a distinct morphological trough. Forsthoff and Holcombe (1983) documented in this region the presence of Quaternary turbidites mainly bioclastic and terrigenous indicating turbidite supply from the insular slope, the onshore areas and the platform. However, the multibeam bathymetry data does not show a consistent connection between the drainage network, located mainly in the talus, and the trough (Fig. 5b). There are no channels/canyons which by-pass the thrust belt and reach the trough.

The western trough is located to the south of the Mona Passage and the Dominican Republic. Here the insular slope is significantly wider ( $>90 \mathrm{~km})$ and the thrust belt is broader $(\sim 45 \mathrm{~km})$. In this region of the insular slope is associated with larger slope basins (e.g., Yuma Basin, San Pedro Basin) and elongated bathymetric barriers which work as effective traps for the turbidite flows. For instance, the San Pedro Basin is limited to the south of a high east-west trending bathymetric barrier and traps the flow of the rivers in southeast Dominican Republic (Ladd et al., 1981; Heubeck et al., 1991). The turbidites have pelagic composition in this region (Forsthoff and Holcombe, 1983), which supports the notion that turbidite supply from the onshore areas and the platform does not reach the western trough. The turbidite supply to the western trough would be essentially derived from the adjacent lower slope, and also from the Venezuelan Basin. Consequently the sediment fill in the western trough is thinner relatively than the eastern segment.

\subsection{Boundary between the Puerto Rico-Virgin Islands and Hispaniola blocks in the Muertos margin}

From seismological and seismic data, Byrne et al. (1985) proposed the existence of the Hispaniola and Puerto Rico platelets, separated by a north-south boundary within the Mona Passage (Fig. 1). Recent GPS studies also suggest a boundary between the slower-moving Hispaniola and the faster-moving Puerto Rico-Virgin Islands area in the Mona Passage (movements relative to North American plate), where late Neogene rifting occurs in a broad zone with an opening rate of 5 mm/yr (Jansma et al., 2000; Calais et al, 2002; Mann et al., 2002).

We do not observe any prominent structures in the southern slope similar to those in the northern slope (e.g., Mona Rift System, MRS in Fig. 1 ), which can accommodate the differential motions between the Hispaniola and the Puerto Rico blocks. The Mona Rift System is limited to the south by the Desecheo Ridge (DR in Fig. 1). This rift system does not continue toward the top of the island arc and there is no connection with south slope structures. Our bathymetry data shows a more or less continuous east-west trending Muertos margin, with transfer zones yielding a minor segmentation in the lower slope. Our data does not support the breaking of the Muertos margin in two parts. We therefore suggest that the accommodation of the east-west differential motion between Hispaniola microplate and Puerto Rico-Virgin Islands block takes place in the Mona Passage area as diffuse deformation. Diffuse deformation could take place by means of the normal faults observed in the upper slope and also at the top of carbonate platform, as was documented by van Gestel et al. (1998). The Muertos thrust belt accommodates the north-south convergence, not an east-west extension. The north-south trending Yuma Basin (YB in Figs. 1, 7b) is mainly located at the boundary between the upper slope and the top of the island arc (Case and Holcombe, 1980; Grindlay et al., 1997) and does not show southwards continuation into the Muertos thrust belt. Moreover, the flanks of the rift are onlapped by the recent horizontally-deposited sediment layers (Fig. 7b) implying no active role in the regional tectonics.

\subsection{Variations in the width of the Muertos thrust belt}

The Muertos thrust belt (essentially the lower and middle slopes) is $45-50 \mathrm{~km}$ wide at the western end of the survey area $\left(69.5^{\circ} \mathrm{W}\right)$, and becomes gradually narrower eastward to $<25 \mathrm{~km}$ in the eastern end of the survey area $\left(66.5^{\circ} \mathrm{W}\right)$ (Fig. 4$)$.

Scaled analogue models have been designed to simulate the formation of fold-and-thrust belts and accretionary wedges (Calassou et al., 1993; McClay et al., 2004). These experiments show that the asymmetrical development of the accretionary complex responds to many different factors in the experimental design. Lateral variations in the volume of the thrusted and accreted foreland sediment can affect to the width of the accretionary prism. In the Muertos foreland area the materials which could be added to the thrust belt are the Venezuelan Basin cover (Carib beds) and the trough wedge. Seismic data indicates that the Carib beds do not show significant variations in thickness along the margin, and therefore, variations in sediment thickness are not a determinant parameter. Sediment volume in the trough wedge is larger in the eastern trough than in the western trough (Fig. 4c). If the volume of accreted sediment was a determinant parameter, we should observe a wider thrust system in the eastern region than in the western region. Since this is not the observed 
situation (Fig. 4a), the volume of the trough wedge is not responsible for the asymmetry of the thrust belt.

In sand models with different depths to the underthrusted plate, the shallower part of the thrusted plate, relative to the deeper part, has smaller volume of trough wedge, shorter spacing between thrust planes, and smaller width of the thrust system (Calassou et al., 1993). The Muertos thrust belt does not show any significant differences in the depth to the underthrusted plate region of change in the trough's depth (AUF in Fig. 4b). Therefore the depth to the underthrusted plate does not seem to have much influence on the width and fault spacing of the thrust belt.

Another possible cause for the asymmetry of thrust belts is the geometry and location of the backstop (Calassou et al., 1993). The geological conditions of the foreland region do not determine the asymmetry of the Muertos thrust belt. It would therefore be necessary to consider the different position and geometry of the backstop (i.e., island arc core) as the cause of the observed asymmetry (ten Brink et al., in press). The different position and geometry of the backstop could be related to the block tectonics proposed for the island arc (Jansma et al, 2000; Mann et al, 2002). More research is needed to investigate this suggestion (see discussion in ten Brink et al, in press).

\subsection{Map-view geometry of the thrust belt}

Several narrow recesses and broad salients can be observed along the strike of the deformation front and the lower slope (Figs. 3a, b; 8; see ruled areas in Fig. 4a). The recesses are concave and are associated with transfer zones. The salients are convex to the direction of transport and salients protrude toward the foreland with respect to the recesses (Marshak, 2004). The thrusting of seamounts and basement highs are common causes for recesses in fold-and-thrust belts and accretionary prisms. This thrusting gives rise to damage tracks throughout the deformed belt (Dominguez et al, 2000; Marques and Cobbold, 2002). The interaction of seamounts or basement highs with the thrust belt yields recesses due to two effects: lower volume of sediment being accreted and tectonic erosion (Scholl et al., 1980). Many seamounts and volcanic bodies have been observed in the central Venezuelan Basin region (Jany, 1989; Driscoll and Diebold, 1999). A seamount has also been interpreted beneath the Muertos thrust belt in the proximity of the Beata Ridge (Mauffret and Leroy, 1999). In our survey area we have identified a seamount and several basement highs (intrusive bodies) in the Muertos Trough and beneath the thrust belt, but thrusted basement highs do not show any observable effect in the deformation front, possibly because of their relatively small size (Figs. 4b, 7d). However, some of the documented volcanic bodies in the Venezuelan Basin region appear to be large and deform or protrude the seafloor (Jany, 1989; Driscoll and Diebold, 1999). The geometry of the observed recesses, the damage track throughout the deformed belt and their location (only in the lower slope) lead us to consider that they may be caused by interactions between the thrust belt and basement highs of the underlying Caribbean plate. The map-view geometry of recess and salients is quite symmetric suggesting north-south convergence in the Muertos margin region.

\section{Summary and conclusions}

Three morphotectonic provinces can be distinguished in the eastern Greater Antilles southern slope on the basis of structural and sedimentological criteria: the lower, middle, and upper slopes. The different provinces are interpreted as corresponding to different stages of development in the accretion process. Active accretion takes place in the lower slope, while a minor accretion occurs in the middle slope. The upper slope is characterized by a shallower extensional tectonics and by extended slope deposit which buries an inactive imbricate structure and the island arc basement.
The normal faults observed in the foreland region of the central Muertos margin could be a consequence of greater development of the thrust belt. These normal faults probably develop in response to the overburden yielded by the differential volume of accreted material.

The width of the Muertos thrust belt decreases eastward. The geological conditions of the foreland region do not explain satisfactorily the asymmetry. It therefore would be necessary to consider the different position and geometry of the backstop (i.e., island arc core) as the cause of the observed asymmetry, as discussed in ten Brink et al. (in press).

The eastern trough located offshore of Puerto Rico, does not have a distinct morphological expression and contains a higher volume of turbidite wedge than the western trough, located to the south of Hispaniola and Mona Passage. These differences are influenced by variations of the turbidite supply from onshore areas and the insular slope, because the supply from the Venezuelan Basin and along the trough axis is minor, and may be restricted by the normal faults that cross the trough in the vicinity of $68^{\circ} \mathrm{W}$.

Our data do not support a north-south trending crustal boundary in the Muertos margin. Accommodation of the ongoing east-west differential motion between the Hispaniola and the Puerto RicoVirgin Islands blocks probably takes place in the Mona Passage area by diffuse deformation, and is not observable in the Muertos thrust belt.

The map-view geometry of recesses and salients observed along the lower slope of the thrust belt and the absence of strike-slip faulting suggest a north-south convergence between the Venezuelan Basin crust and the Muertos thrust belt. This observation contrasts with a previously proposed oblique convergence along the Muertos margin.

\section{Acknowledgements}

We thank the Captain, officers and crew of the $R / V$ Hespérides and the sea-going technicians from the Unit. Tec. Marítima and the U.S. Geological Survey for their professional help at sea. The project is supported by the Ministerio de Educación y Ciencia: Spanish project REN2003-08520-C02 and complementary action REN2002-12855-E/ MAR, the U.S. Geological Survey Coastal and Marine Geology Program, and the Puerto Rico Seismic Network. J. L. Granja was supported by a PhD. grant from Ministerio de Educación y Ciencia. The unmigrated seismic images (Fig. 7) were provided by Marine Seismic Data Center, University of Texas Institute for Geophysics. http://www.ig.utexas. edu/sdc/. We thank the EW9501 cruise chief scientists J. B. Diebold and N. Driscoll for allowing us to use seismic profile 1292.

Fig. 1 was drafted using free software Generic Mapping Tools (Wessel and Smith, 1998). Fig. 4a and b were drafted using free software SAGA GIS. We also thank Pilar Llanes, Jason Chaytor, Clauida Flores, Nina Kukowski, and Paul Mann for constructive comments at different stages of manuscript preparation.

\section{References}

Allaby, M., 2008. Dictionary of Earth Sciences, third ed. Oxford University Press. 654p. Biju-Duval, B., Bizon, G., Mascle, A., Muller, C., 1982. Active margin processes; field observations in southern Hispaniola. American Association of Petroleum Geologist Memoir 34, 325-344.

Brown, K.M., Westbrook, G.K., 1987. The tectonic fabric of the Barbados ridge accretionary complex. Mar. Petrol. Geol. 4, 71-81.

Burke, K., Fox, P.J., Sengor, M.C., 1978. Buoyant ocean floor and the evolution of the Caribbean. J. Geophys. Res. 83 (B8), 3949-3953.

Byrne, D.B., Suarez, G., McCann, W.R., 1985. Muertos Trough subduction, microplate tectonics in the northern Caribbean? Nature 317, 420-421.

Calais, E., Mazabraud, Y., Mercier de Lepinay, B., Mann, P., Mattioli, G., Jansma, P., 2002. Strain partitioning and fault slip rates in the north-eastern Caribbean from GPS measurements. Geophys. Res. Lett. 29, 1856. doi:10.1029/2002GL015397.

Calassou, S., Larroque, C., Mallavieille, J., 1993. Transfer zones of deformation in thrust wedges: an experimental study. Tectonophysics 221, 325-344.

Carbó, A., Córdoba, D., Martín Dávila, J., ten Brink, U., Herranz, P., Von Hilldebrandt, C., Payero, J., Muñoz Martín, A., Pazos, A., Catalán, M., Granja, J.L., Gómez, M., GEOPRICO-DO Working Group, 2005. New marine geophysical survey explores 
active tectonics at north-eastern Caribbean plate boundary. Eos, Trans., Am. Geophys. Union 86 (51), 537,540 20Dec2005.

Case, J.E., Holcombe, T.L., 1980. Geologic-tectonic map of the Caribbean region: Reston, Virginia, USA, U. S. Geological Survey Miscellaneous Investigations Series Map I-1100, scale: $1: 2,500,000$.

Catalán, M., Martín-Dávila, J., Calzadilla, M., Carbó, A., Córdoba, D., 2008. Geomagnetic field mapping of the Northern Caribbean Region, from Lesser Antilles to Hispaniola Island. Transactions of the 18th Caribbean Geological Conference, p. 13.

Charvet, J., Ogawa, Y., 1994. Arc-trench tectonics. In: Hancock, P.L. (Ed.), Continental Deformation. Pergamon Press, University of Bristol, U. K., pp. 180-198.

Davis, E.E., Hyndman, R.D., 1989. Accretion and recent deformation of sediments along the northern Cascadia subduction zone. Geological Society of America Bulletin 101, $1465-1480$.

Diebold, J.B., Stoffa, P.L., Buhl, P., Truchan, M., 1981. Venezuelan Basin crustal structure. J. Geophys. Res. 86 (B9), 7901-7923.

Diebold, J.B., Driscoll, N.W. and EW9501 Team, 1999. New insights on the formation of the Caribbean basalt province revealed by multichannel seismic images of volcanic structures in the Venezuelan Basin. In: Hsü, K.J., (Series Ed.). Sedimentary Basins of the World, 4. Caribbean Basins. Mann, P. (Ed), Elsevier Science, N. Y. 561-589.

Dillon, W.P., Edgar, N.T., Scanlon, K.M., Coleman, D.F., 1996. A review of the tectonic problems of the strike-slip northern boundary of the Caribbean plate and examination by Gloria. Geology of the United States' Seafloor: The View from GLORIA, vol. 9, pp. 135-164.

Driscoll, N.W., Diebold, J.B., 1999. Tectonic and stratigraphic development of the eastern Caribbean: new constraints from multichannel seismic data. In: Hsü, K. J., (Series Ed.). Sedimentary Basins of the World, 4. Caribbean Basins. Mann, P. (Ed), Elsevier Science, N. Y. 591-626.

Dolan, J.F., Mullins, H.T., Wald, D.J., 1998. Active tectonics of north-central Caribbean: oblique collision, strain partitioning, and opposing subducted slabs. In: Dolan, J., Mann, P. (Eds.), Active Strike-slip and Collisional Tectonics of the Northern Caribbean Plate Boundary Zone. Geological Society of America, Special Paper, vol. 326, pp. 1-62.

Dominguez, S., Malavielle, J., Lallemand, S.E., 2000. Deformation on accretionary wedges in response to seamount subduction. Insights form sandbox experiments. Tectonics 19, 182-196.

Donnelly, T.W., 1973. Magnetic anomaly observations in eastern Caribbean Sea. In: Edgar, N.T., Saunders, J.B., et al. (Eds.), Initial Reports of de DSDP 15. U. S. Government Printing Office, Washington, pp. 1023-1029.

Edgar, N.T., Ewing, J.I., Hennion, J., 1971. Seismic refraction and reflection in Caribbean Sea. Am. Assoc. Petrol. Geol. Bull. 55, 833-870.

Edgar, N.T., Saunders, J.B., et al., 1973. Initial Reports of the Deep Sea Drilling Project, 15. D. C. U. S. Govt., Washington. 1137p.

Ewing, J., Talwani, M., Ewing, M., 1968. Sediment distribution in the Caribbean Sea: 4th Caribbean Geological Conference. Proceedings 317-323 (Trinidad and Tobago, 1965).

Forsthoff, G.M., Holcombe, T.L., 1983. Quaternary turbidites of Muertos Trough northeastern Caribbean sea. Composition, source and dispersal patterns. 10th Caribbean Geological Conference. Proceedings, pp. 353-367.

Garrison, L.E., 1972. Acoustic-reflection profiles, eastern Greater Antilles: U. S. Geological Survey Pub. No. USGS-GD-72-004.

Glover III, L., 1971. Geology of the Coamo area, Puerto Rico, and its relation to the volcanic arc-trench association. U. S. Geological Survey. Professional Paper, vol. 636, p. 102.

Gnibidenko, H.S., Svarichevskaya, L.V., 1983. The submarine canyons of Kamchatka. Mar. Geol. 54, 277-307.

Granja, J.L., Carbó-Gorosabel, A., Muñoz-Martín, A., Ballesteros, M.G., Martín Dávila, J., Córdoba, D., 2006. Morphotectonic analysis of the Muertos Trench and the Muertos Deformed Belt, north-eastern Caribbean plate (Geoprico-Do Project). Geophys. Res. Abstr. EGU06-A-06860.

Granja Bruña, J.L., Carbó-Gorosabel, A., Muñoz-Martín, A., Llanes Estrada, P. 2008. Gravity maps in the northeastern Caribbean plate boundary zone. 2008. Transactions of the 18th Caribbean Geological Conference, p. 27.

Grindlay, N.R., Abrams, L.J., Del Greco, L., Mann, P., 2005. Toward an integrated understanding of Holocene fault activity in western Puerto Rico: constraints from high-resolution seismic and sidescan sonar. In: Mann, P. (Ed.), Active Tectonics and Seismic Hazards of Puerto Rico, The Virgin Islands, and Offshore Areas. Geological Society of America, Special Paper, vol. 385, pp. 139-160.

Grindlay, N.R., Mann, P., Dolan, J., 1997. Researchers investigate submarine faults north of Puerto Rico. Eos, Trans., Am. Geophys. Union 78 (38), 404-404. doi:10.1029/ 97EO00262, 1997.

Hagen, R.A., Bergersen, D.D., Moberly, R., Coulbourn, W.T., 1994. Morphology of a large meandering submarine canyon system on the Peru-Chile forearc. Mar. Geol. 119, 7-38.

Heubeck, C., Mann, P., Dolan, J., Monechi, S., 1991. Diachronous uplift and recycling of sedimentary basins during Cenozoic transpression, northeastern Caribbean plate margin. Sediment. Geol. 70, 1-32.

Hilde, T.W.C., 1983. Sediment subduction versus accretion around the Pacific. Tectonophysics 99, 170-174.

Jansma, P.E., Mattioli, G.S., Lopez, A., DeMets, C., Dixon, T.H., Mann, P., Calais, E., 2000. Neotectonics of Puerto Rico and the Virgin Islands, northeastern Caribbean, from GPS geodesy. Tectonics, $196,1021-1037$.

Jany, I., 1989, Neotectonique au sud des Grandes Antilles, collision (ride de Beata, Presqu'ile de Bahoruco); subduction (fosse de Muertos); transtension (passage d'Anegada) [Ph.D. thesis]: Paris, Université Pierre-et-Marie-Curie (Paris-VI), 306 p. (marine geophysical mapping of active faulting at the northern end of the Beata Ridge, the Muertos Trench, and the Anegada Passage).

Kearey, M., 2001. Dictionary of Geology, second ed. Penguin Books. 327p.

Kopp, C., Fruehn, J., Flueh, E.R., Reichert, C., Kukowski, N., Bialas, J., Klaeschen, D., 2000 Structure of the Makran subduction zone from wide-angle and reflection seismic data. Tectonophysics 329, 171-191.
Kukowski, N.. Schillhorn, T., Huhn, K., von Rad, U., Husen, S., Flueh, E.R., 2001. Morphotectonics and mechanics of the central Makran accretionary wedge off Pakistan. Mar. Geol. 173, $1-19$.

Ladd, W.J., Worzel, J.L., Watkins, J.S., 1977. Multifold seismic reflections records from the northern Venezuela basin and the north slope of Muertos trench. Marine Science Institute. University of Texas, 41-56.

Ladd, J.W., Watkins, J.S., 1978. Active Margin structures within the north slope of the Muertos Trench. Geologie en Mijnbouw 57 (2), 255-260.

Ladd, J.W., Watkins, J.S., 1979. Tectonic development of trench-arc complexes on the northern and southern margins of the Venezuela Basin. Am. Assoc. Petrol. Geol. Memoir 29, 363-371.

Ladd, J.W., Shih, Tai-Chang, Tsai, C.J., 1981. Cenozoic tectonics of central Hispaniola and adjacent Caribbean Sea. Am. Assoc. Petrol. Geol. Memoir 65, 466-489.

Ladd, J.W., Holcombe, T.L., Westbrook, G.K., Edgar, N.T., 1990. Caribbean marine geology: active margins of the plate boundary. In: Dengo, G., Case, J.E. (Eds.), The Geology of North America, Vol. H. The Caribbean Region. A Decade of North American Geology. Geological Society of America, Boulder, Colorado, pp. 261-290.

Lallemand, S., Cadet, J.P., Jolivet, L., 1986. Mécanisme de tectogenenese a la base du mur interne de la fosse du Japon (au large de Sanriku, Japon NE) rejeu des failles océaniques sous la marge. C. R. Acad. Sci. Paris 302, 319-324.

Larue, D.K., Ryan, H.F., 1998. Seismic reflection profiles of the Puerto Rico Trench: shortening between the North American and Caribbean plates. In: Lidiak, E.G. Larue, D.K. (Eds.), Tectonics and Geochemistry of the Northeastern Caribbean Special Paper, 322. Geological Society of America, pp. 193-210.

Marques, F.O., Cobbold, P.R., 2002. Topography as a major factor in the development of arcuate thrust belts; insights from sandbox experiments. Tectonophysics 348 (4), $247-268$.

McClay, K.R., Whitehouse, T.D., Richards, M., 2004. 3D evolution of fold and thrust belts formed by oblique convergence. Mar. Petrol. Geol. 21, 857-877.

Malfait, B.T., Dinkelman, M.G., 1972. Circum-Caribbean tectonic and igneous activity and the evolution of the Caribbean plate. Geol. Soc. Am. Bull. 83, 251-272.

Manaker, D., Calais, E., Freed, A., Ali, T., Przybylski, P., Mattioli, G.S., Jansma, P.E., Pre petit, C., deChabalier, J.-B., 2008. Interseismic plate coupling and strain partitioning in the Northeastern Caribbean. Geophys. J. Int. 174 (3), 889-903.

Mann, P., Burke, K., 1984. Neotectonics of the Caribbean. Rev. Geophys. Space Phys. 22 (4), 309-362.

Mann, P., Draper, G., Lewis, J., 1991. Overview of the geologic and tectonic development of Hispaniola. In: Mann, P., Draper, G., Lewis, J.F. (Eds.), Geologic and Tectonic Development of the North America-Caribbean Plate Boundary in Hispaniola. Special Paper, vol. 262. Geological Society of America, pp. 1-28.

Mann, P., Taylor, F.W., Edwards, R.L., Ku, T.L., 1995. Actively evolving microplate formation by oblique collision and sideways motion along strike-slip faults: an example from north-western Caribbean plate margin. Tectonophysics 246, 1-69.

Mann, P., 1999. Caribbean sedimentary basins: classification and tectonic setting from Jurassic to present. in: Hsü, K.J., (Series Ed.). Sedimentary Basins of the World, 4. Caribbean Basins. Mann, P. (Ed), Elsevier Science, N. Y. 4, 3-31.

Mann, P., Calais, E., Ruegg, J.-C., DeMets, C., Jansma, P.E., 2002. Oblique collision in the north-eastern Caribbean from GPS measurements and geological observations. Tectonics 2 (6), 1057. doi:10.1029/2001TC0011304,2002.

Mann, P., Hippolyte, J.-C., Grindlay, N., Abrams, L.J., 2005. Neotectonics of southern Puerto Rico and offshore margin. In: Mann, P. (Ed.), Active Tectonics and Seismic Hazards of Puerto Rico, The Virgin Islands, and Offshore Areas. Special Paper, vol. 385. Geological Society of America, pp. 173-214.

Marshak, S., 2004. Salients, recesses, arcs, oroclines, and syntaxes. A review of ideas concerning the formation of map-view curves in fold-thrust belts. In: McClay, K.R. (Ed.), Thrust Tectonics and Hydrocarbons Systems. Am. Assoc. Petrol. Geol. Memoir, vol. 82, pp. 131-156.

Masson, D.G., Scanlon, K.M., 1991. The neotectonic setting of Puerto Rico. Geol. Soc. Am. Bull. 103, 144-154.

Matthews, J., Holcombe, T., 1974. Possible Caribbean underthrusting of the Greater Antilles along Muertos Trough. Transactions of the 7th Caribbean Geological Conference (Guadeloupe), pp. 235-242.

Matthews, J., Holcombe, T., 1985. Venezuelan Basin of the Caribbean Sea - stratigraphy and sediment distribution. Mar. Geol. 68, 1-23.

Mauffret, A., Leroy, S., 1999. Neogene intraplate deformation of the Caribbean plate at the Beata Ridge. In: Hsü, K. J., (Series Ed.). Sedimentary Basins of the World, 4. Caribbean Basins. Mann, P. (Ed), Elsevier Science, N. Y. 627-669.

Moore, G.F., Karig, D.E., 1976. Development of sedimentary basins on the lower trench slope. Geology 4, 693-697.

Moore, J.C., Biju-Duval, B., 1984. Tectonic synthesis, Deep Sea Drilling Project Leg 78A: structural evolution of offscraped and underthrust sediment, northern Barbados ridge complex. Init. Repts DSDP 78, 601-621.

Mutti, E., Ricci Lucchi, F., 1978. Turbidites of the northern Appenines: introduction to facies analysis. Int. Geol. Rev. 20,125-166.

Ranero, C.R., Villaseñor, A., Phipps Morgan, J., Weinrebe, W., 2005. Relationship between bend-faulting at trenches and intermediate-depth seismicity. Geochem., Geophys. Geosyst. - G3 6 (no.12), 25.

Reid, J.A., Plumley, P.W., Schellekens, J.H., 1991. Paleomagnetic evidence for late Miocene counterclockwise rotation of north coast carbonate sequence, Puerto Rico. Geophys. Res. Lett. 18, 565-556.

Scholl, D., von Henue, R., Vallier, T., Howell, D., 1980. Sedimentary masses and concepts about tectonic processes at underthrust ocean margins. Geology 8, 564-568.

Shipley, T.H., McIntosh, K.D., Silver, E.A., Stoffa, P.L., 1992. Three-dimensional seismic imaging of the Costa Rica accretionary prism: structural diversity in a small volume of the lower slope. J. Geophys. Res. 97, 4439-4459. 
Shipley, T., Gahagan, L., Johnson, K., Davis, M. (Eds.), 2005. Seismic Data Center. University of Texas Institute for Geophysics. URL=http://www.ig.utexas.edu/sdc/.

Silver, E.A., Galewsky, J., McIntosh, K.D., 1995. Variation in structure, style, and driving mechanism of adjoining segments of the North Panama deformed belt. Geol. Soc Am., Special Paper 295, 225-233.

Smith, W.H.F., Sandwell, D.T., 1997. Global seafloor topography from satellite altimetry and ship depth soundings. Science 277, 1957-1962.

Stolt, R.H., 1978. Migration by Fourier transform. Geophysics 43, 23-48.

ten Brink, U., Lin, J., 2004. Stress interaction between subduction earthquakes and forearc strike-slip faults: modeling and application to the northern Caribbean plate boundary. J. Geophys. Res. 109, B12310. doi:1029/2004JB003031, 2004.

ten Brink, U., Danforth, W., Polloni, C., Andrews, B., Llanes, P., Smith, S., Parker, E., Uozumi, T., 2004. New sea floor reveals the structure of the Puerto Rico. Trench and helps assess earthquake and tsunami hazards in the Northeast Caribbean. Eos, Trans. Am. Geophys. Union 85 (37), 349-354.

ten Brink, U.S., 2005. Vertical motions in the Puerto Rico trench and Puerto Rico and their cause. J. Geophys. Res. 100, B06404. doi:10.1020/2004JB003459, 2005. ten Brink, U.S., Marshak, S., Granja, J.L., in press. Bivergent thrust wedges surrounding island arcs: Insights from observations and sandbox models of the northeastern Caribbean plate. Geological Society of America Bulletin.

Underwood, M.B., 1991. Submarine canyons, unconfined turbidite currents, and sedimentary bypassing of forearc region. Rev. Aquatic Sci. 4 (2-3), 149-200.

van Gestel, J.-P., Mann, P., Grindlay, N.R., Dolan, J.F., 1998. Structure and tectonics of the upper Cenozoic Puerto Rico-Virgin Islands carbonate platform as determined from seismic reflection studies. J. Geophys. Res. 103 (B12), 30,505-30,530.

Weber, J.C., Dixon, T.H., DeMets, C., Ambeh, W., Jansma, P., Mattioli, G., Saleh, J., Sella, G., Bilham, R., Pérez, O., 2001. GPS estimate of relative motion between the Caribbean and South American plates, and geologic implications for Trinidad and Venezuela. Geology 29 (1), 75-78.

Wessel, P., Smith, W.H.F., 1998. New improved version of Generic Mapping Tools released. Eos, Trans., Am. Geophys. Union 79 (47), 579.

Worzel, J.L., Ewing, M., 1954. Gravity anomalies and structure of the West Indies, pt. 2. Geol. Soc. Am. Bull. 65, 195-199. 